\title{
Sedimentary geology of the Palaeoarchaean Buck Ridge (South Africa) and Kittys Gap (Western Australia) volcano-sedimentary complexes
}

\author{
Sjoukje T. de Vries, Wouter Nijman*, Poppe L. de Boer \\ Sedimentology Group, Department of Earth Sciences, Utrecht University, Budapestlaan 4, 3584 CD Utrecht, The Netherlands
}

\section{A R T I C L E I N F O}

\section{Article history:}

Received 7 May 2010

Received in revised form 1 September 2010

Accepted 22 September 2010

\section{Keywords:}

Archaean sedimentary basins

Archean sedimentology

Barberton Greenstone Belt

Coppin Gap Greenstone Belt

East Pilbara granite-greenstone terrane Chert

\begin{abstract}
A B S T R A C T
The two Palaeoarchaean volcano-sedimentary complexes of the Buck Ridge (Barberton Greenstone Belt, South Africa) and Kittys Gap (Coppin Gap Greenstone Belt, East Pilbara, Australia) have a similar geological setting and age $(\sim 3.45 \mathrm{Ga})$. The predominantly volcaniclastic sediments are concentrated at the top of these complexes, and experienced thorough, (very) early diagenetic silicification. In many places the silicification process has led to excellent preservation of the primary sedimentary structures. Elsewhere it has resulted in their obliteration or replacement by diagenetic structures. The Buck Ridge chert forms a regressive-transgressive succession, deposited around base level, with lacustrine and littoral marine facies. Deposition of the Kittys Gap Chert was also close to base level, almost exclusively subaqueous, with tidal influence and a regressive sequential trend.

In both volcano-sedimentary complexes, these low-energy sediments are juxtaposed with high-energy breccia pods and layers, with often a high Fe-oxide content. The breccias are interpreted as being the result of explosive hydrothermal activity. Sedimentation was strongly controlled by normal faulting.
\end{abstract}

(c) 2010 Elsevier B.V. All rights reserved.

\section{Introduction}

We discuss two well-preserved Palaeoarchaean silicified sedimentary rock units (cherts), that both form the top of intraformationally faulted complexes of intrusive and extrusive felsic rocks, minor basalts, felsic volcaniclastic sedimentary rocks and sedimentary cherts, further indicated as a volcano-sedimentary complex (vsc):

- the Buck Ridge Chert ${ }^{1}\left(\mathrm{BRC}^{2}\right)$ of the $~ 3.45-3.41$ Ga Buck Ridge volcano-sedimentary complex (BR-vsc, uppermost Hooggenoeg Formation, Onverwacht Group), located on the northern limb of a major antiform that affects a large part of the southern Barberton Greenstone Belt (South Africa, Fig. 1).

- the Kittys Gap Chert (KGC) of the 23.45 Ga Kittys Gap volcanosedimentary complex (KG-vsc, Panorama and possibly Strelley Pool Formations ${ }^{3}$ ) in the Coppin Gap Greenstone Belt (Pilbara, Western Australia, Fig. 2).

\footnotetext{
* Corresponding author.

E-mail address: wnijman@geo.uu.nl (W. Nijman).

1 or Buck Reef Chert (Lowe and Byerly, 1999).

2 The term BRC is applied from the level where the sedimentary succession has been thoroughly silicified, a transition that is clearly visible on aerial photographs.

3 The entire KG-vsc was previously considered to belong to the Panorama Fm (e.g., Nijman et al., 1998b; De Vries et al., 2006b; Westall et al., 2006), However, Hickman (2008) considers the KGC to be part of the Strelley Pool Formation, a formation separating the Warrawoona and Kelly Groups, and the felsic part of the KG-vsc as belonging to the Panorama Fm in the top of the Warrawoona Group.
}

The BR-vsc and KG-vsc are underlain and overlain by major successions of mostly extrusive mafic to ultramafic rocks.

The exposed length of the BR-vsc is at least $15 \mathrm{~km}$ (for a detailed map see Nijman and De Vries, 2009). Apart from minor chert layers in the lower part, the sedimentary rocks are concentrated along the top of the complexes, above, lateral to, and partly alternating with felsic volcanic rocks. In both areas, the felsic volcanic rocks and sediments were deposited concurrent with large-scale normal (growth) fault activity (Nijman and De Vries, 2004; De Vries et al., 2006a,b). The syndepositional tectonism produced pronounced thickness variations across the faults (maximum thickness in the hanging walls; minimum thickness in the footwalls, Figs. 1 and 2), block rotations and roll-over anticlines. The thickness variations decrease upward in the stratigraphic succession.

The felsic lavas and intrusive TTG (tonalite-trondhjemitegranodiorite) rocks of the BR-vsc are $3451 \pm 5$ Ma old (De Vries et al., 2006a; SHRIMP zircon U-Pb $\mathrm{Zr}$ dating ${ }^{4}$ ), whereas the volcaniclastic rocks were assigned a maximum age of $3416 \pm 5$ Ma by Kröner et al., 1991; Pb-Pb evaporation dating. Along the southern limb of the Onverwacht Bend, the BRC is either absent (e.g. Viljoen and Viljoen, 1969), or represented by 'three chert layers inter-bedded with thicker volcanic units' (Lowe et al., 1985; Lowe and Byerly, 1999). The volcanic units include massive and pil-

\footnotetext{
4 The GPS coordinates of dating sample LV01-23 were mentioned incorrectly in Table 3 of De Vries et al., 2006a. The correct coordinates are: S 2555'33.6" /E 30 '54'07.1".
} 


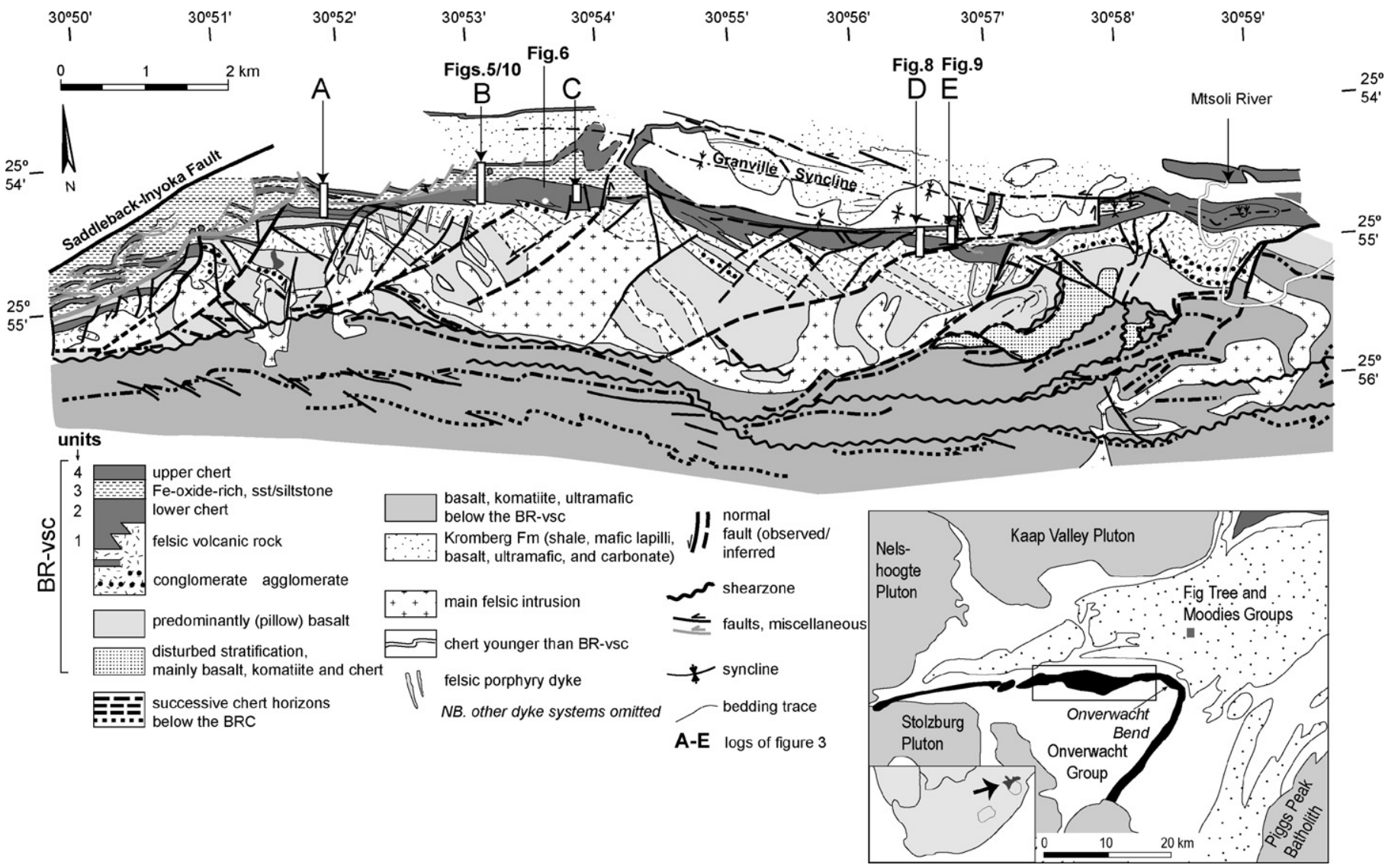

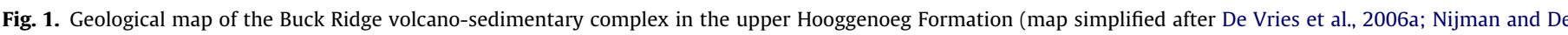

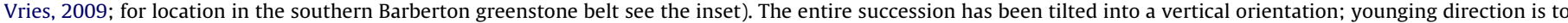
the north. A-E refers to log locations. Locations of Figs. 5, 6, 8-10 are indicated. Legend applies to the main figure, not to the inset.

low basalts, mafic pyroclastic layers, komatiitic flows and intrusive units.

The sedimentology of the BRC has been the subject of several recent studies: Lowe and Fisher Worrell (1999) described evaporitic facies in the lowermost part of the BRC, Tice and Lowe (2004) described the environment of formation of photosynthetic microbial mats in the BRC, Tice and Lowe (2006) studied the distribution of carbonaceous material in the various chert facies, while De Vries et al. (2006a) focused on the growth-fault controlled architecture.

The KG-vsc is exposed over a length of $\sim 5 \mathrm{~km}$. The complex is sandwiched between pillow basalts of the underlying Apex and overlying Euro Basalts. The felsic igneous rocks of the KG-vsc have an age of $3446 \pm 5 \mathrm{Ma}$ (U-Pb SHRIMP dating, De Vries et al., 2006b). The KGC forms the silicified sedimentary (chert) top of the complex (Fig. 2).

Growth-fault control on the deposition of the KGC sediments was first mentioned by Nijman et al. (1998b), and further elaborated in Van Kranendonk et al. (2001), Nijman and De Vries (2004) and De Vries et al. (2006b). Biological and geochemical aspects of the KGC were described by Westall et al. (2006), Orberger et al. (2006) and Rouchon and Orberger (2008).

In studies of pre-3.3 Ga sedimentary rock units, the link between micro- to mesoscale sedimentological features on the one hand and the overall geological setting on the other hand is still fragmentary. Detailed analysis of the geometry of the sedimentary deposits should help to fill this gap. Therefore, in the facies analysis of this paper, the one-dimensional, vertical variation in the sequential architecture (bedding, grainsize trends, primary and secondary sedimentary structures), and the lateral variation in the geometry of the chert units have been given more emphasis than the detailed sediment petrography. The interpretation of the depositional environment is given in two steps. The first step, consisting of an environmental diagnosis that can be directly derived from the observations, is given immediately after the description of the geometry and facies of each stratigraphical unit. The interpretation of the succession and lateral variation of stratigraphical units, which relate to the basin fill as a whole, are given in summary interpretations for the BR-vsc (Section 2.6) and the KG-vsc (Section 3.4) respectively.

In both areas, silicification has locally led to an excellent preservation of sedimentary textures and structures, which elsewhere have been partly or completely obliterated by the same process. In combination with synsedimentary deformation, this syndepositional to early diagenetic silicification, to an extent hardly known on modern Earth, complicates the interpretation of the sedimentary successions, and is therefore addressed as well (Section 4).

\section{Sedimentology of the Buck Ridge Chert and related volcaniclastic deposits}

\subsection{Stratigraphic subdivision, geometry and structural features}

Fig. 1 gives an overview of the extent and distribution of the sedimentary succession at the top of the BR-vsc, including the locations of sedimentary logs A-E (Figs. 3 and 4). Four sedimentary units are distinguished in the BRC. They are particularly well exposed in the central part of the map area (units 1-4; Figs. 1, 4 and 5). Thicknesses of the BRC proper here vary between $\sim 100 \mathrm{~m}$ (footwall thickness) and $\sim 530 \mathrm{~m}$ (hanging-wall thickness). Post-depositional, $\sim 3.228 \mathrm{Ma}$ pyroxene-amphibole porphyry dykes and sills intruded 

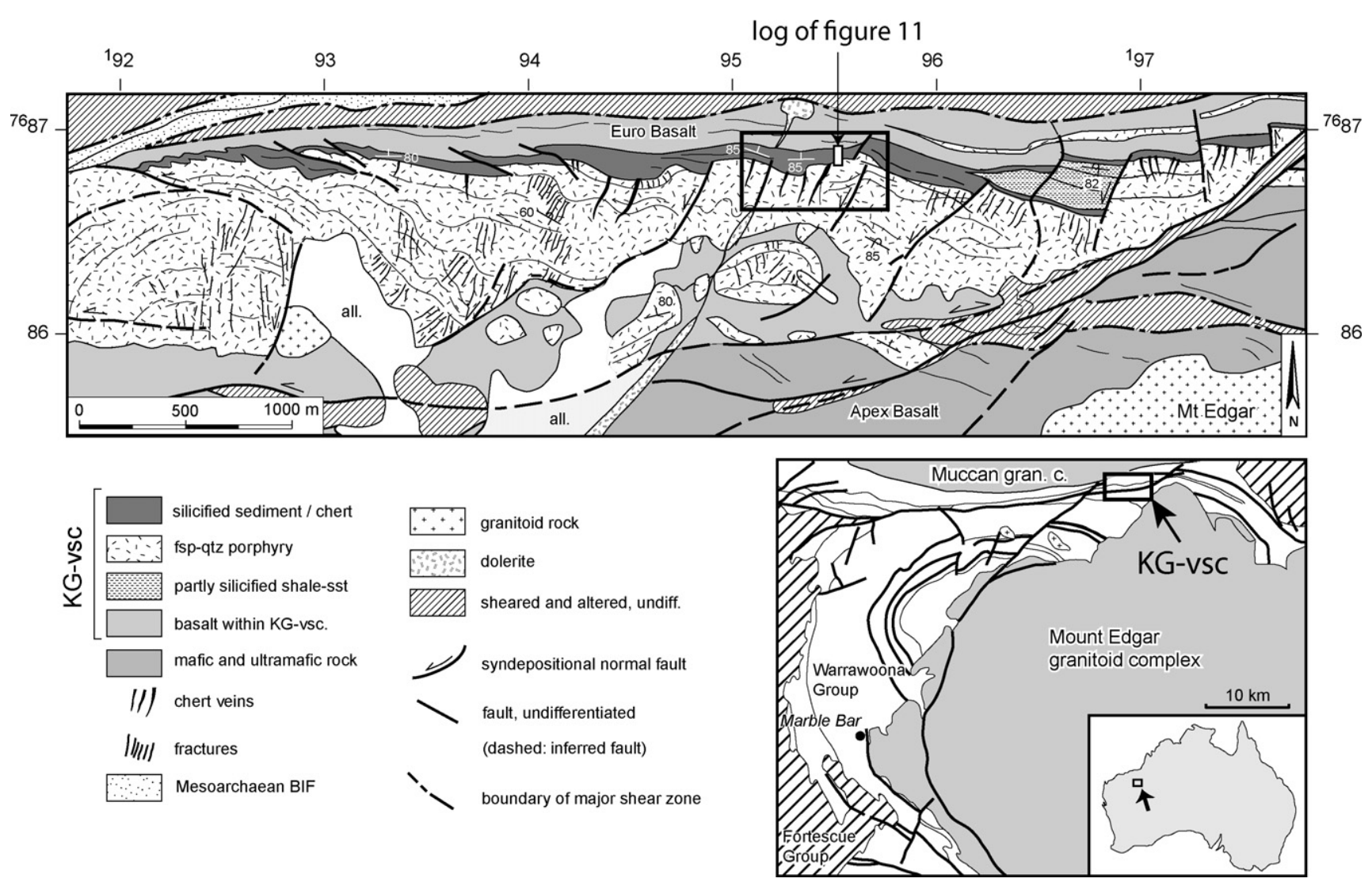

Fig. 2. Geological map of the Kittys Gap volcano-sedimentary complex (KG-vsc, Panorama Formation; map after De Vries et al., 2006b). The main study area is indicated by a rectangle, the location of figure within the Coppin Gap Greenstone Belt is indicated in the inset. Legend applies to the main figure, not to the inset. Map grid is Australian Map Grid, Zone $51 \mathrm{~K}$.

\section{Legend to logs}

\section{Composition and texture}

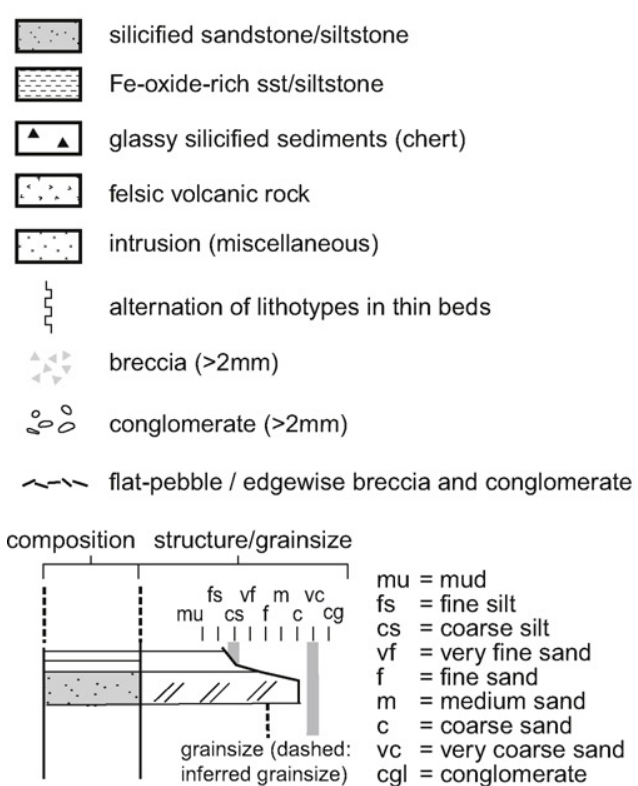

\section{Internal bedding structures}

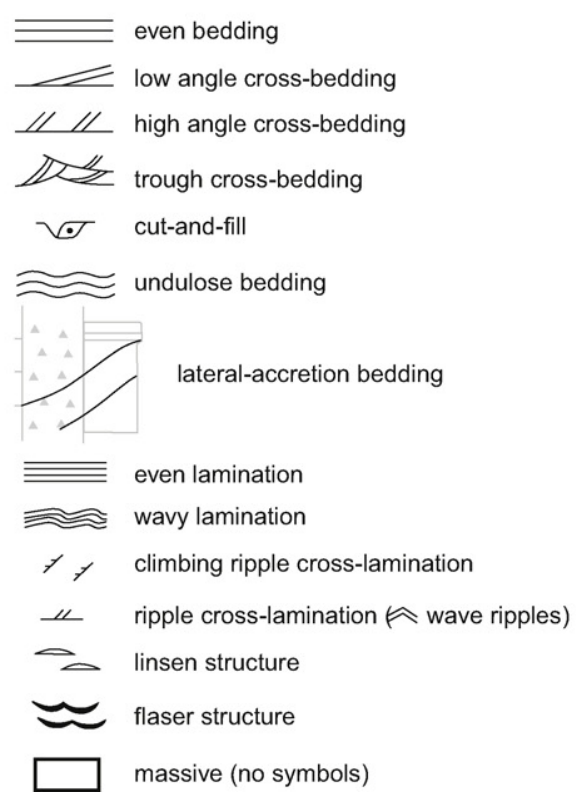

\section{Sedimentary / diagenetic structures}

e current ripples

A wave ripples

v load cast

$\tau$ ball \& pillow

$\Omega$ convolute lamination

$\square$ stalactite cement

M stylolites

$\infty$ shelter structure

$\infty$ elongate bedding-parallel cavity fill,

$\infty$ sheet crack

oo outsized, glassy pebbles

$\infty$ patchy silicification

Fe high iron-oxide concentration

(a) Liesegang rings

Fig. 3. Legend to sedimentary logs of Figs. 4, 8, 10 and 11. Grain sizes have been measured on relic sedimentary textures preserved in the chert. 


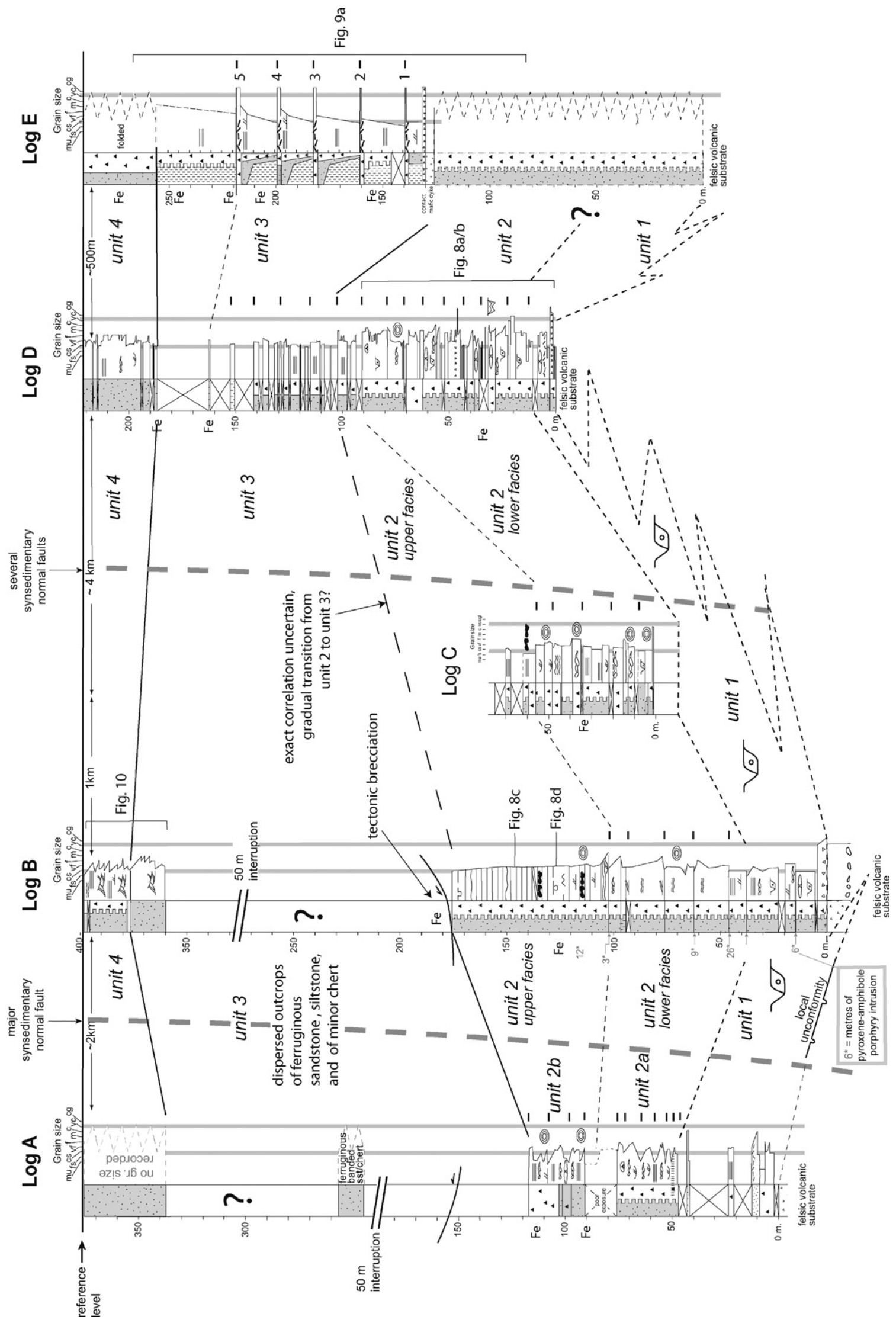

Fig. 4. Correlation of sedimentary logs of the BRC (legend in Fig. 3). The top of unit 4 is taken as a reference level. For log locations see Fig. 1, detailed parts of logs in other figures are indicated. Correlation of the sections is also based on high- and low-level aerial photographs. 
into units 1 and 2 (Fig. 5; dating by De Vries et al., 2006a). Locally, they occupy up to about $15 \%$ of the thickness of the BRC, but detailed mapping has shown that part of this $15 \%$ replaces original sediments. West of $\log \mathrm{A}$, the stratigraphic succession in the uppermost part of the BR-vsc is more varied due to the intercalation of basalts. There, units 2-4 are strongly affected by late syndepositional to early post-depositional, low-angle extensional faulting, accompanied by detachment, rotation and thrusting of blocks derived from the local chert substrate (Fig. 1 and De Vries et al., 2006a). The reconstructed thickness of the BRC in that area is over $1000 \mathrm{~m}$.

Parts of the BRC have been described in detail and interpreted by Lowe and Fisher Worrell (1999, their lithofacies 1-7; our unit 1) and by Tice and Lowe (2004, 2006; our units 1 and 2).

\subsection{BRC unit 1: Interdigitated chert with volcanic rocks}

\section{Geometry and large-scale structure}

The base of unit 1 is difficult to establish because of the transitional and interdigitated contact with the underlying felsic volcanic rocks. The maximum thickness of this unit is $\sim 270 \mathrm{~m}$.

In the central part of the study area, unit 1 is characterised by $100 \mathrm{~m}$-scale scour structures (Figs. 5 and 6). They mainly occur along the hanging walls of the normal faults away from the crests of the fault blocks. The scour structures have been filled progradationally towards the east with downlapping to tangential contacts (Fig. 6a). They contain volcaniclastic deposits, banded chert, minor felsic volcanic rocks and crystal layers (see below).

\section{Facies}

The sedimentary facies of unit 1 comprise mega ${ }^{5}$-trough crossbedded (Fig. 6c and d) and ripple-laminated chert (Fig. 7a-d), even-laminated black-and-white banded and massive grey chert, silicified and non-silicified conglomerate and breccia, and poorly or non-silicified volcaniclastic sediment and lava. Throughout this assemblage, black chert veins occur discordant and parallel to the bedding (Fig. 6b). Several decimetres thick layers with silicified crystals and crystal palisades (described in detail by Lowe and Fisher Worrell, 1999) form another conspicuous component (Fig. 7e-j). This entire facies association is even found to occur within a single mega scour-fill (Fig. 6b).

Breccia layers, occasionally incorporated in the fill of the scours, are $0.5-2 \mathrm{~m}$ thick, and consist of $0.5-20 \mathrm{~cm}$ large black and white banded chert, felsic volcanic and $(<1 \%)$ fuchsitic fragments. At one location a 1.2 by $1 \mathrm{~m}$ block with laminated chert layers and silicified crystals is incorporated in the breccia layer. Where the chert grades laterally into partly or non-silicified felsic volcanic rocks, thin sedimentary chert layers remain intercalated in the volcanosedimentary succession (Fig. 7a). They contain abundant, in places climbing, current ripples (Fig. 7b-d) and layers with reworked accretionary lapilli (Fig. 6e). In the eastern part of the area, some of these cherts form isolated, convex-up, lens-shaped bodies of a few metres wide, composed of massive white chert with mmscale irregularly laminated intervals along the periphery. The lenses occur in an area of relatively densely spaced felsic porphyry dykes and chert veins (see also De Vries et al., 2006a).

Frequently occurring cavities in unit 1-cherts have been partially to completely filled with chert and quartz; some show geopetal structures, with stalactitic quartz or chert at the top and with floors of sediment (Fig. 7a).

The layers with silicified crystals and crystal palisades present a crucial element for the interpretation of the sedimentary environment of unit 1 and of the BRC as a whole. Lowe and Fisher

\footnotetext{
5 Mega: > 4cm set height.
}

Worrell (1999) first observed these layers, continuous over approximately $15 \mathrm{~km}$ along strike of the northern limb of the Onverwacht Bend. They identified the crystals as silicified nahcolite, and interpreted these as evaporites (see below). We observed that the crystal palisades, restricted to unit 1 , are discontinuous, and in places discordant to the bedding. In Fig. 7e, they form linings along the floor and roof (Fig. 7f) of a fracture in felsic volcanic rocks. The fracture dissects obliquely an assemblage of finely-laminated chert and chert-pseudo breccia with black chert veins. At the same location, the convolute-laminated sediments overlie a layer with dish-like structures (Fig. $7 \mathrm{~g}-\mathrm{i}$ ) reminiscent of water-escape structures (cf. Johnson, 1977). Here, they contain tiny black chert veinlets (Fig. 7h,i). Elsewhere, similar black chert veinlets terminate upwards within the crystals (Fig. $7 \mathrm{j}$ ), and laminated sediments between the crystals curve upwards and in places also downwards (Fig. $7 \mathrm{j}$ ) against the silicified crystals.

At log location A and further towards the west, both mega-scour fills and crystal layers are absent and the facies changes to evenbedded black-and-white chert resembling the overlying unit 2 (see below). Towards the east, where the Mtsoli River cuts the upper part of the BR-vsc (Fig. 1), a thick succession of volcaniclastic sediments is the lateral equivalent to unit 1 . These sediments are coarse and include agglomerate (cf. De Wit, 1983) and polymictic pebblecobble conglomerate (Fig. 1). In that area, there is no mappable distinction between BRC units 1 and 2 .

\section{Sedimentological interpretation}

The sedimentary structures of unit 1 , in particular the hundredmetre-scale scour fills (Fig. 6a and b) represent maximum energy conditions for the BRC. Evidence for primary volcanic (pyroclastic) deposition as well as for reworked volcanic (epiclastic) deposits include more or less chertified lava flows, and the cherts with cross-bedded accretionary lapilli and climbing ripples. A possible explanation for the scour fills and associated structures, fitting the other observations, is that they result from pyroclastic surges, related to explosive volcanism under 'moist' conditions (cf. Fisher and Schmincke, 1984: in particular the dunes illustrated in their figures are identical to those in our Fig. 7b-d; Cas and Wright, 1987; Orton, 1996). High net sedimentation ${ }^{6}$ rates are evident from the climbing ripples and their transition into plane bed (Fig. 7b).

The stalactites in cavity fills of unit 1 indicate that these cavities were at least intermittently air-filled. Hence, unit 1 experienced occasional emersion (as also suggested by Lowe and Fisher Worrell, 1999), probably under vadose conditions.

Silicified crystals and crystal palisades in unit 1 were interpreted by Lowe and Fisher Worrell (1999) as marine evaporites. They considered it unlikely that the crystals precipitated from a water body nourished by hydrothermal discharge, because they were 'unable to locate any tufas, spring mounds, or other deposits that are common around hydrothermal discharge sites'. However, the interpretation of the crystal layers as evaporites does not agree with the high level of energy necessary to explain the primary sedimentary structures associated with the crystal layers. Rather, the black chert vein stock works, hydrothermal breccias, and possible sinter deposits in the vicinity of the crystal occurrences, and the local bedding-discordant nature of the crystal layers are indications of a hydrothermally influenced environment (cf. De Vries and Touret, 2007; Hofmann and Harris, 2008). Therefore, the source of the fluid from which these crystals precipitated may well have

\footnotetext{
6 "Net sedimentation" is the amount of sediments involved in a depositional process (e.g. current). If less sediment is available than can be transported, erosion may prevail; at high sediment input the sediment accumulates rapidly as in the case of climbing ripple sets; also, if more sediment is available than can be transported, net sedimentation tends to flatten out primary sedimentary structures.
} 


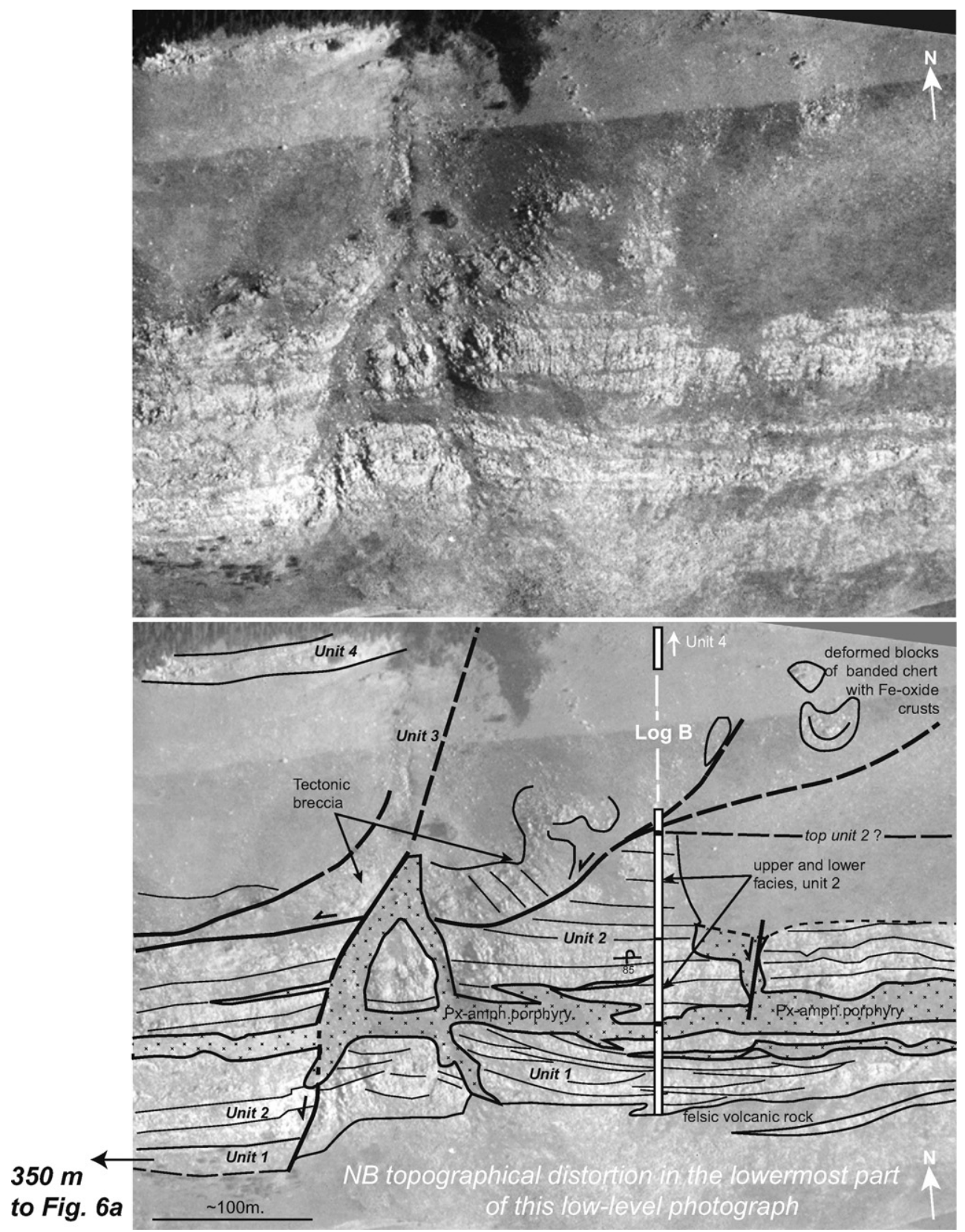

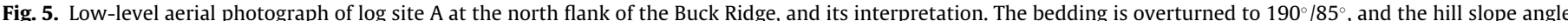

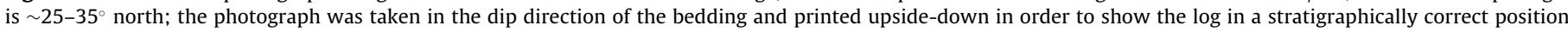

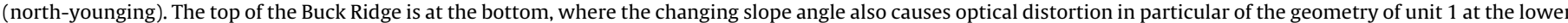

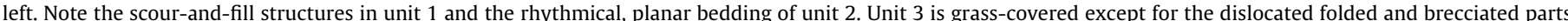

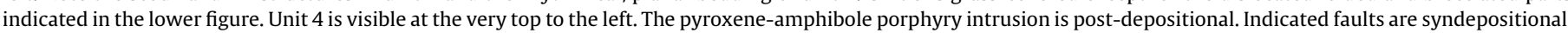

been hydrothermal (see also Van der Boorn et al., 2007). The input of hydrothermal fluids into surface waters thus would have led to the formation of a stratified water body, from which the crystals precipitated. The inferred high energy does only match to an interpretation as evaporitic crystal beds if active sedimentation alternated with prolonged periods of non-sedimentation in standing water. Alternatively, the crystals may have precipitated from hydrothermal fluids below the sediment-water interface. The curvature of the sediment layers between the silicified crystals may have resulted from the force of crystallisation (e.g. Maliva and Siever, 1988) of the growing crystals on the surrounding sediments. Lowe and Fisher Worrell (1999) attributed the curvature to compaction effects adjacent to the crystals because they regarded the deformation to be too small to have been gener- ated by diagenetic crystal growth within sediments. Nevertheless, the observed relationship between black chert veinlets, similarly curved laminations in dish structures, convolute lamination and the palisade crystals, suggests that the common factor was ascending water through poorly compacted fine-grained sediments from one and the same source, here interpreted to be a hydrothermal system.

\subsection{BRC unit 2: Thoroughly silicified, even bedded chert}

Geometry and large-scale structure: Unit 2 is much more evenly bedded than unit 1 , thoroughly silicified, well exposed and up to $200 \mathrm{~m}$ thick. It shows a rhythmic stacking of up to eight wellexposed, 7.5-15 $\mathrm{m}$ thick chert sequences, (Figs. 4 and $8 \mathrm{a}$ and b). 

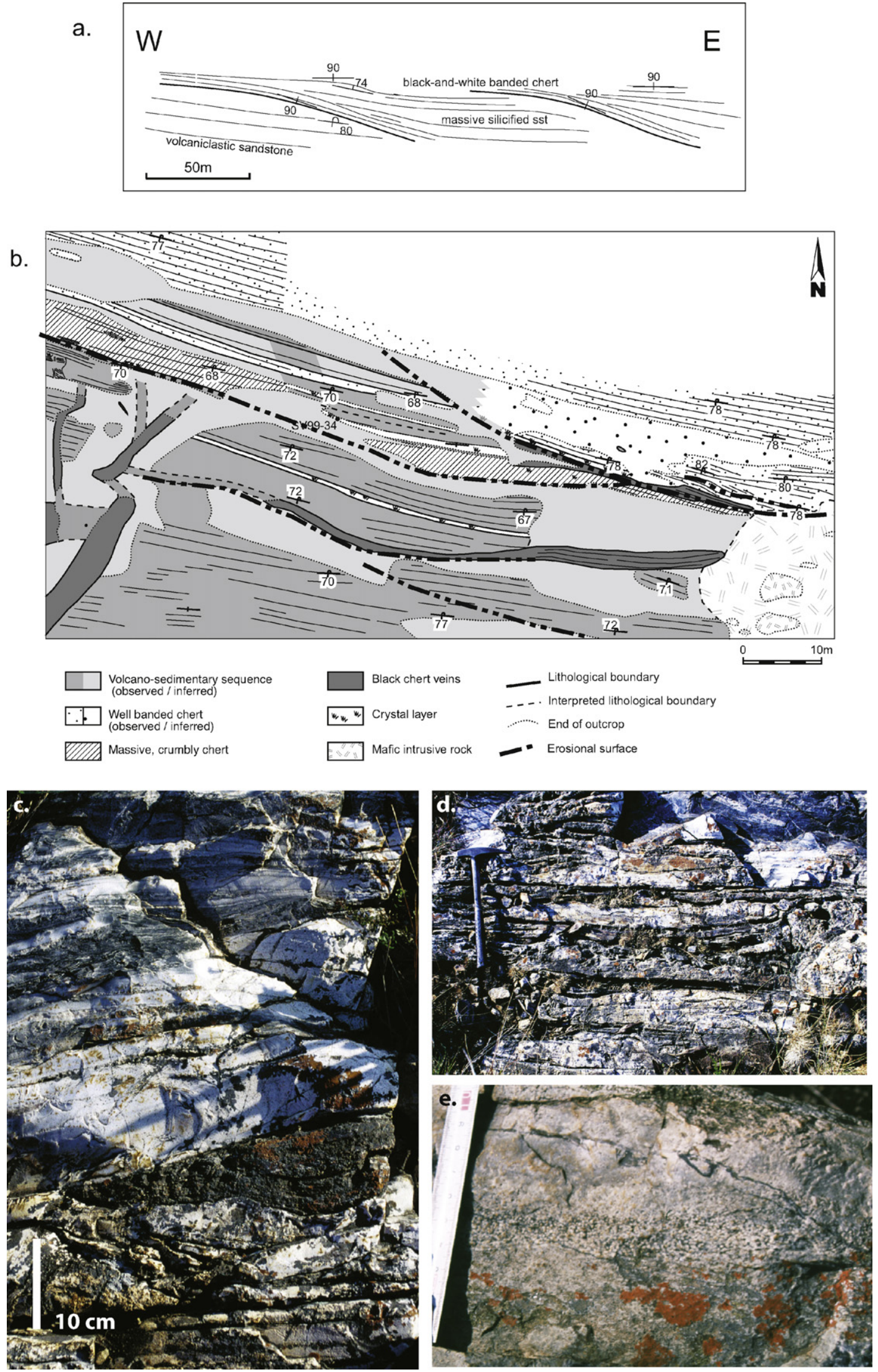

Fig. 6. (a) Outcrop of near-vertically dipping scour-and-fill structures in unit 1 of the BRC, $\sim 350 \mathrm{~m}$ west of $\log \mathrm{B}\left(\mathrm{S} 25^{\circ} 55^{\prime} 19.6^{\prime \prime} / \mathrm{E} 30^{\circ} 52^{\prime} 32.3^{\prime \prime}\right.$ and westwards; drawing from field observations). Infill of the structures is progradational in due eastern direction; (b) $10 \mathrm{~m}$-grid map of outcrop showing BRC unit 1 and contacts with the adjacent units, relationship between cherts, volcanic sediments, crystal palisades, major scour-and-fill structures, and black chert veins. Location indicated in Fig. 1; (c and d) trough cross-bedding in chert of BRC unit I; location north of top Mt. Geluk; (e) silicified trough cross-bedded lapilli sandstones BRC unit I, location: S 25 $55^{\prime} 24.6^{\prime \prime}$ /E 30 $53^{\prime} 38.8^{\prime \prime}$. 
a1.

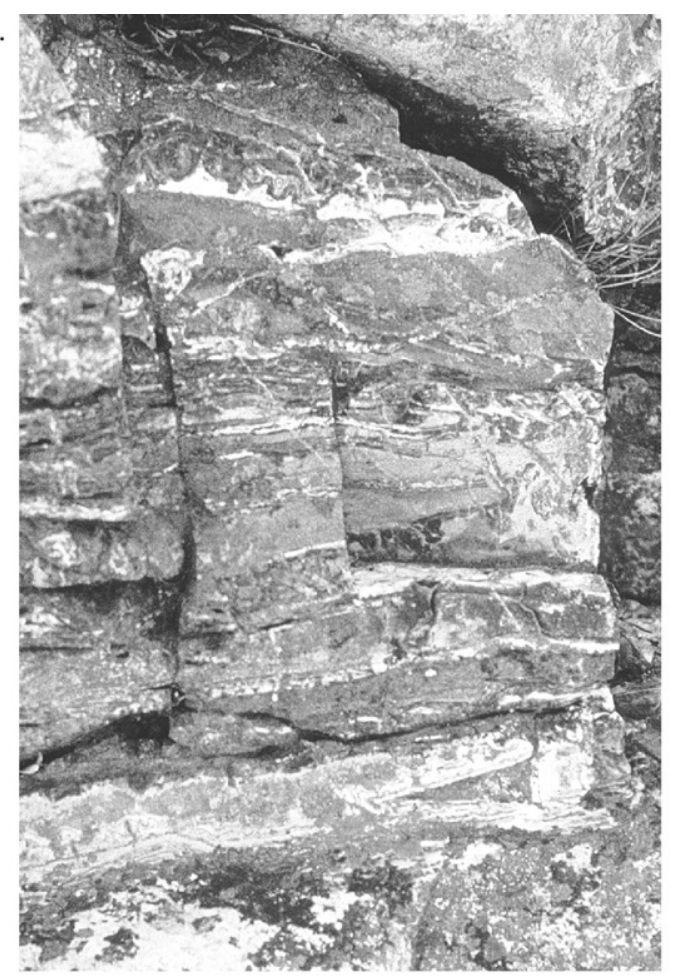

2 .

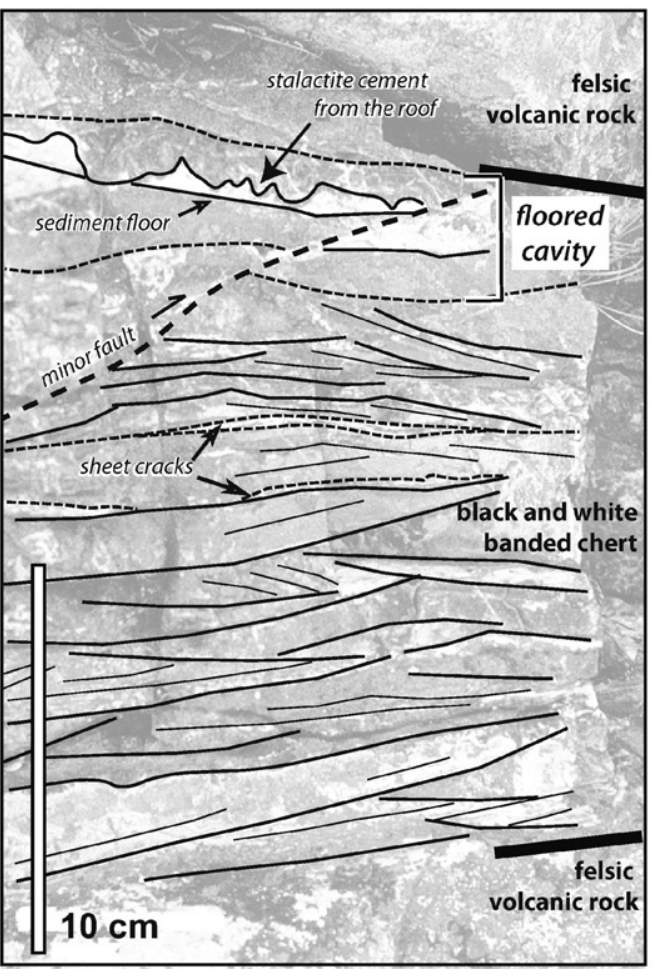

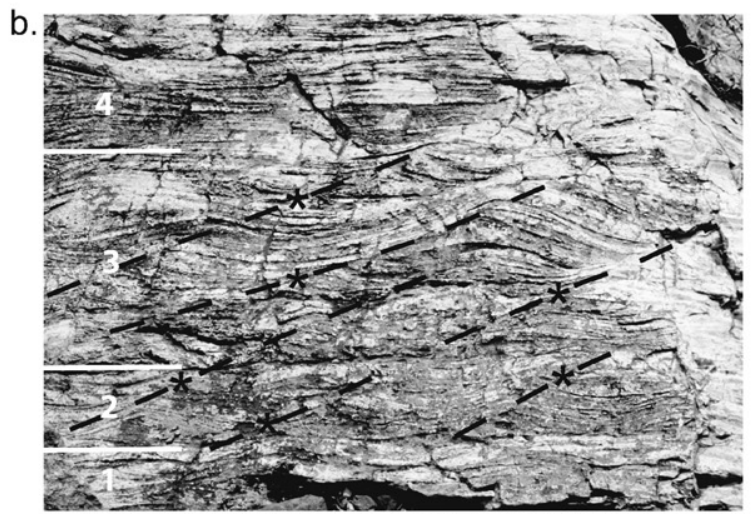
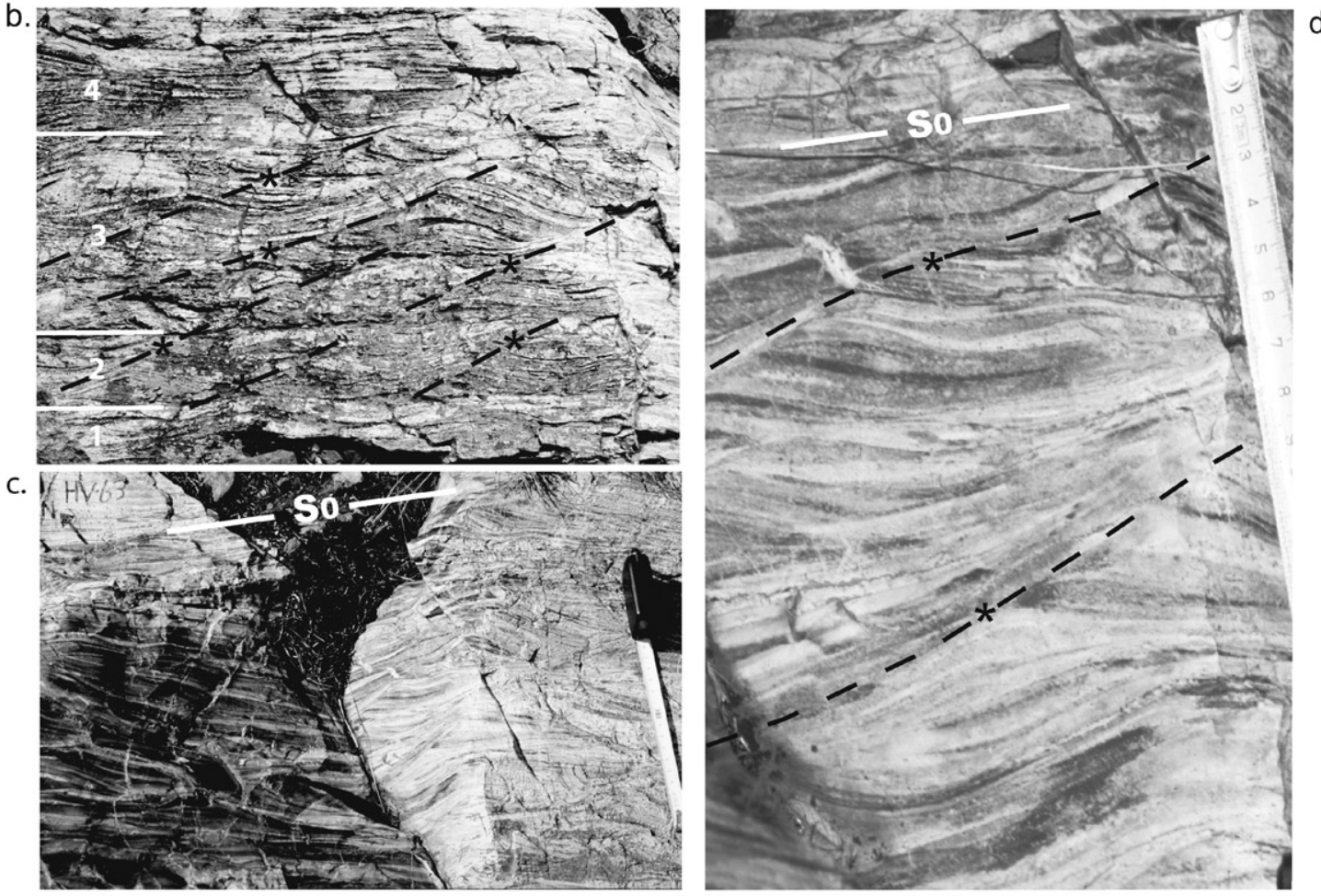

d.

So: bedding orientation; $*$ climbing ripple set boundaries

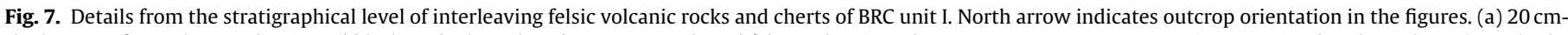

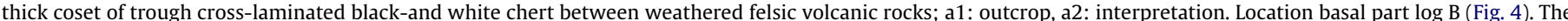

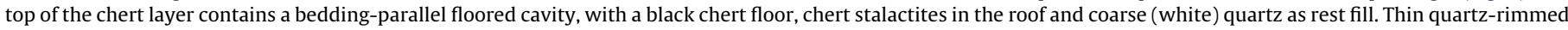

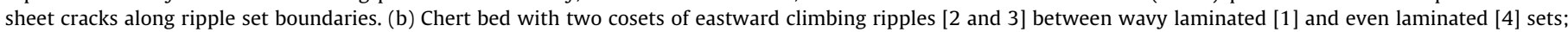

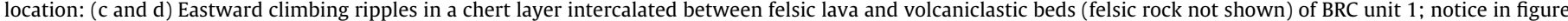

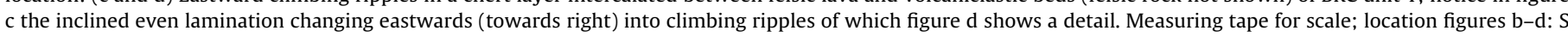

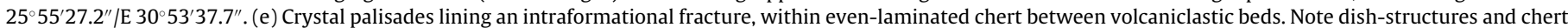

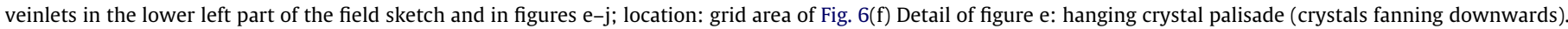

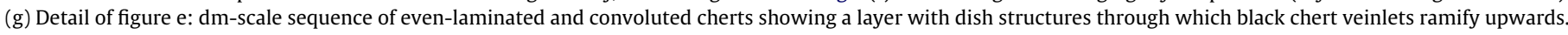

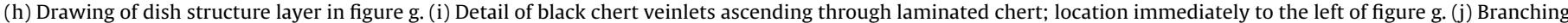

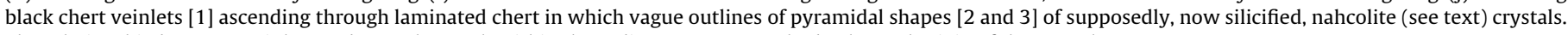
The relationship between veinlets and crystal growth within the sediment suggests a hydrothermal origin of the crystals. 


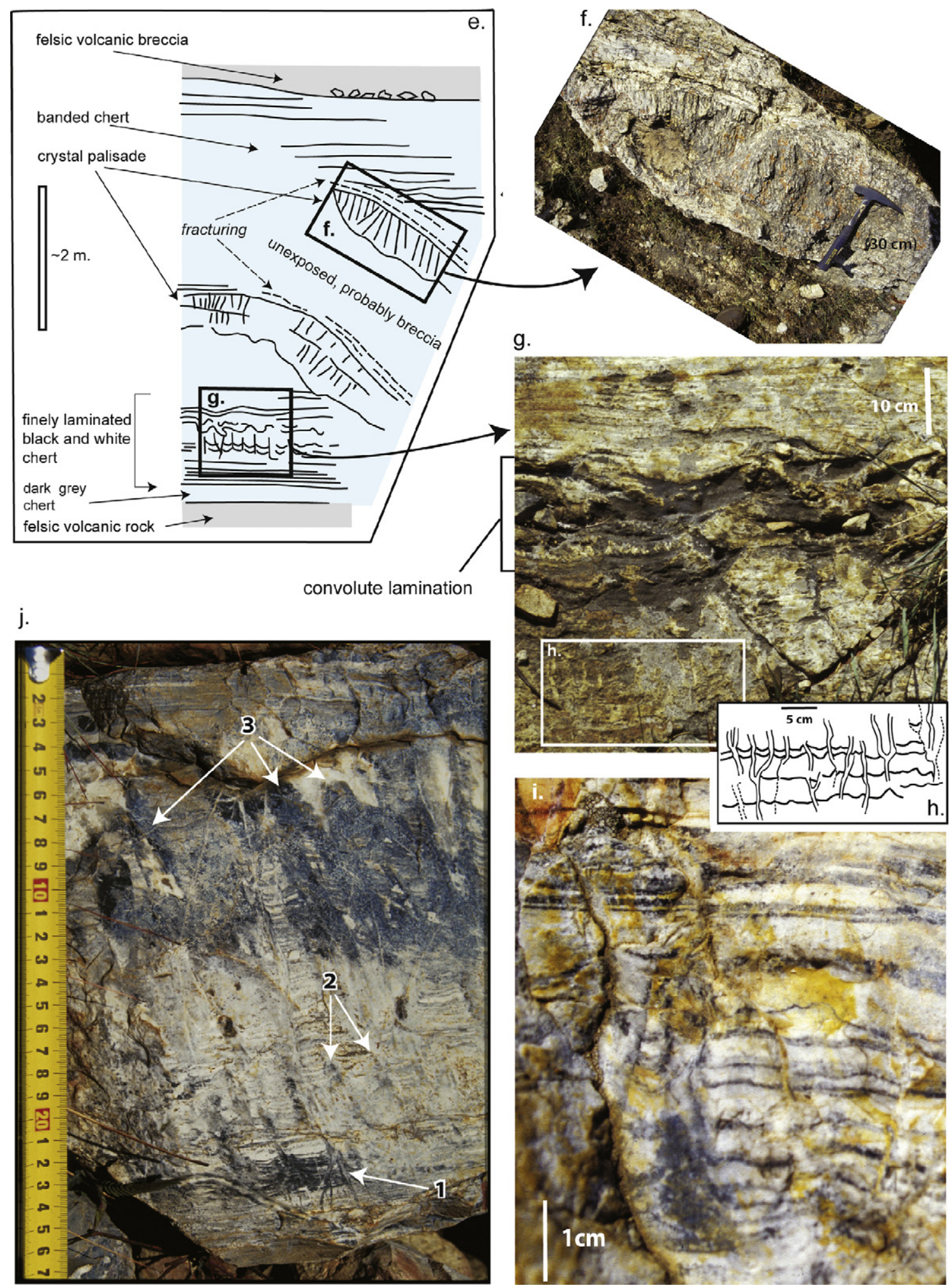

Fig. 7. (Continued).

In $\log A$, located at the crest of a rollover anticline (Figs. 1 and 4 ), unit 2 is only $70 \mathrm{~m}$ thick, and splits up into two subunits, $2 \mathrm{a}$ and $2 \mathrm{~b}$, separated by a poorly exposed interval.

Facies: The well-exposed parts of the sequences are mostly glassy silicified, with good preservation of primary and secondary structures. Both coarsening-up and fining-up grain size trends are observed (Fig. 8a). In the lower part of unit 2, metre-scale, trough cross-laminated, often pebble-lined cut-and-fill structures occur, particularly near the bases of the stacked sequences. They are overlain by $3-10 \mathrm{~cm}$ thick layers of generally planar-bedded sandstone and chert. Soft-sediment deformation structures and quartz-filled sheet cracks are abundant. Pebbles occur isolated, intercalated in coarse, sandy sediments, sometimes in stacks with coarse quartz cement in between. Occasionally, the unit includes thin, finely 
a.

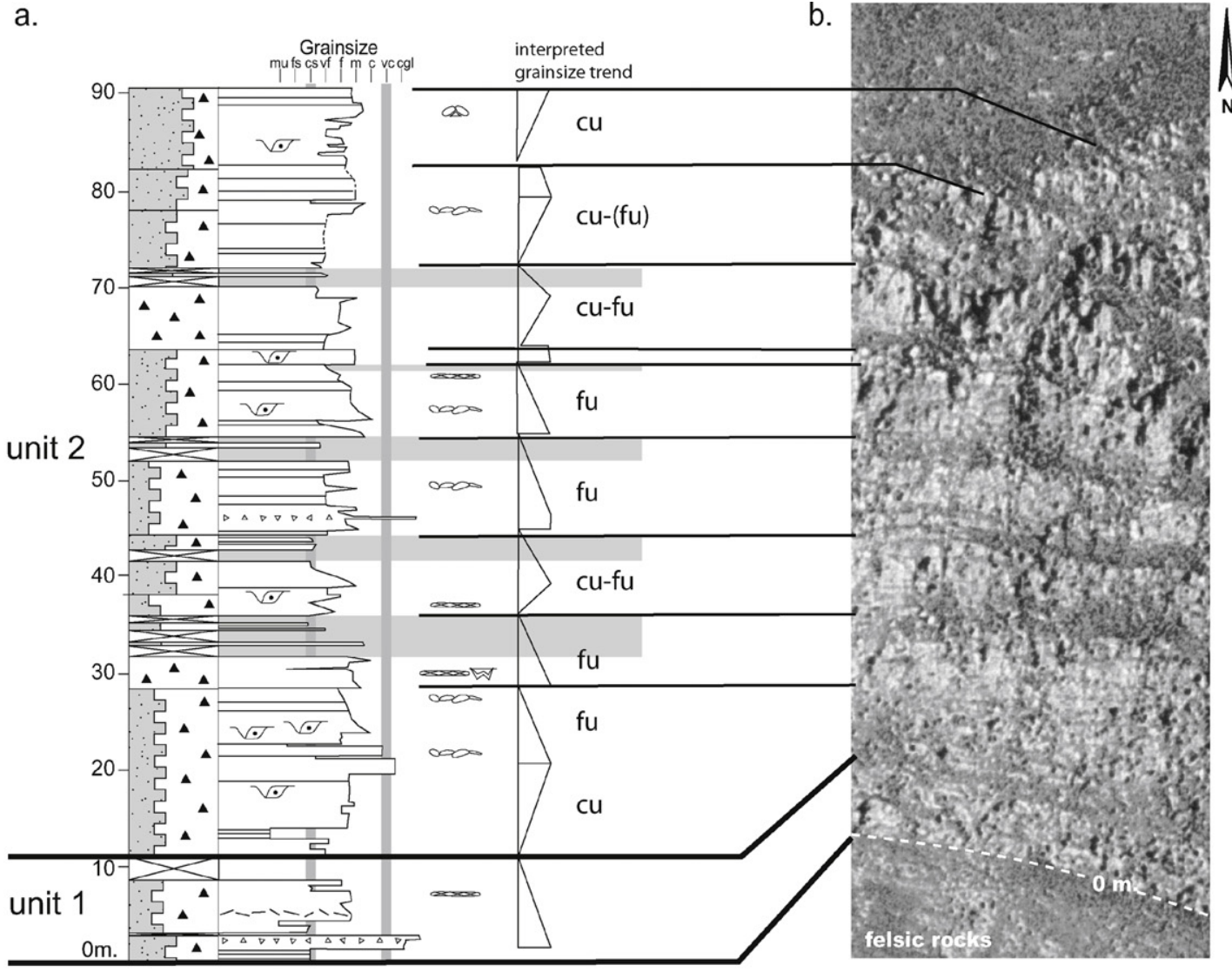

c.
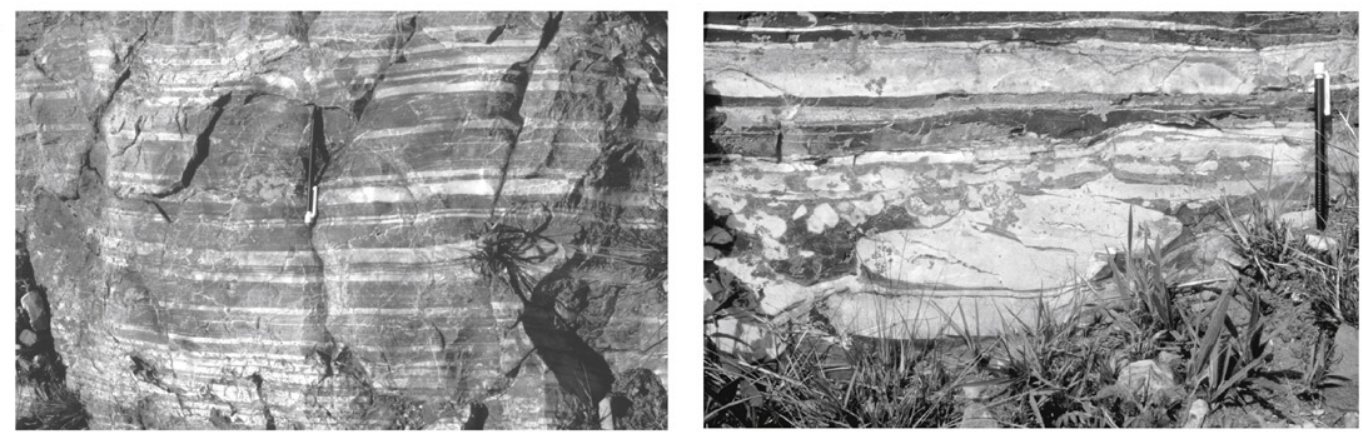

e.
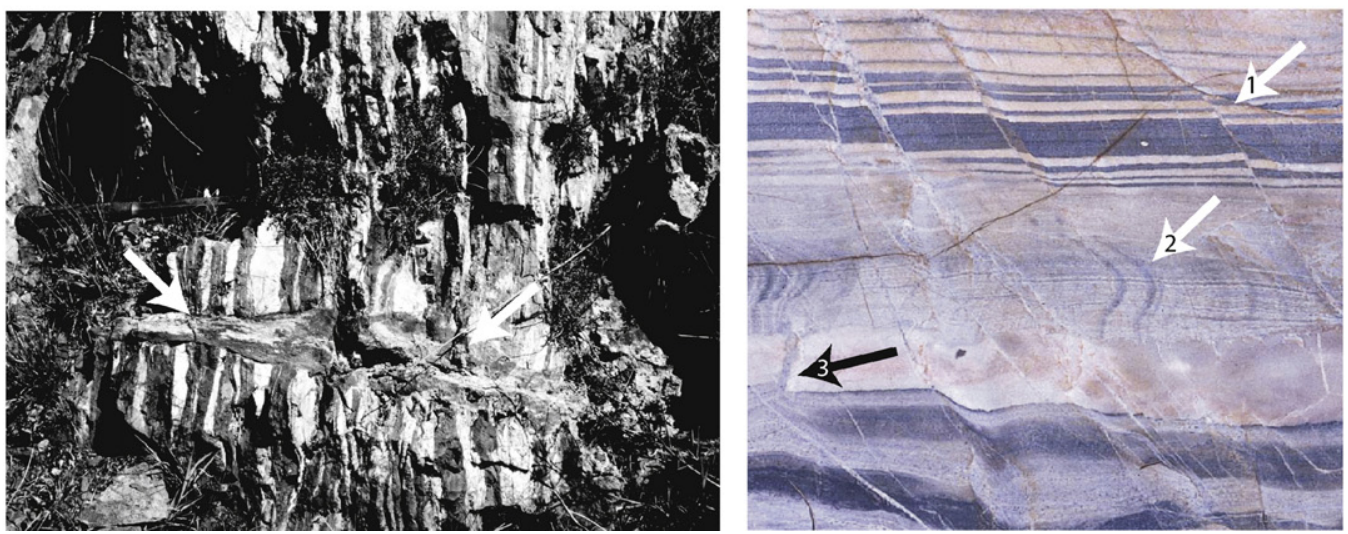

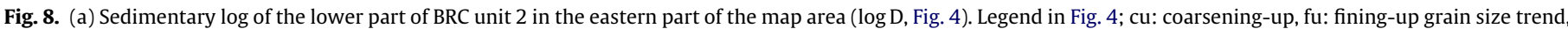

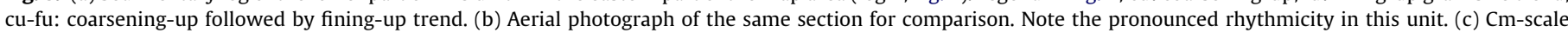

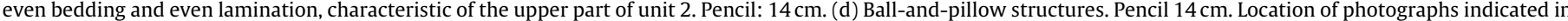

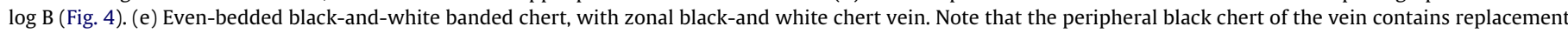

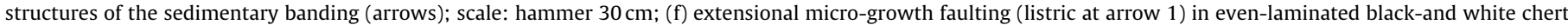
with silica-Liesegang banding (2); sand dike (arrow 3 ). 
banded iron-oxide-rich sandstone and chert alternations at the top of these sequences (e.g. $\log$ C, Fig. 4 ).

The facies in the uppermost part of unit 2 is characterised by very fine sandy to silty planar bedding. It is well exposed in the central area $(\log$ B, Fig. 4), where it consists of extremely even-bedded black-and-white banded chert (Fig. 8c, e and f) with structures resembling ball-and-pillow structures (Fig. 8d), with chert veins (Fig. 8e) and silicification fronts resembling Liesegang rings (Fig. 8f; see Section 4).

The facies of the two cherts ( $2 a$ and $2 b$ ) in the west does not differ fundamentally from that of the corresponding parts of unit 2 more to the east (Fig. 4). The grain size is definitely smaller, even lamination more pronounced, and silicification both in black and white chert remarkably glassy. Unit 2a shows coarseningfining up sequences, most of them containing one, often imbricated, flat-pebble breccia bed (cf. Plate 1a). Trough cross-bedding is common. Unit $2 \mathrm{~b}$ is one grade finer than unit $2 \mathrm{a}$, even lamination preponderant and flat pebble conglomerate/breccia occurs more frequently. Relatively much Fe-oxide is found, in particular in unit 2b. Liesegang rings follow this trend, as they do also in the lower part of unit 2 at $\log C$ (Fig. 4).

Sedimentological interpretation: Although $100 \mathrm{~m}$-scale scour structures as observed in unit 1 are absent, the presence of metrescale cut-and-fill structures and trough cross-bedding, notably in the lower part of the unit, indicates that energy conditions remained relatively high, though still in the lower flow regime. For the unit as a whole, the energy level decreased at the transition from the lower to the upper part. Energy conditions varied, as is indicated by the reversals of grain size trends and the distribution of trough cross-bedding and even bedding. The poorly sorted, repeated stacks of outsized pebbles in the coarse-grained sediments indicate that either mass transport was an important process, or otherwise the breaking-up of early silicified layers by incidental storm activity. For the interpretation of the flat-pebble beds, see the next section.

As in unit 1, stalactite and stalagmite-filled cavities, particularly in the lower part of unit 2 more to the east, suggest occasional emersion.

The planar-bedded, fine-grained sediments in the upper part of unit 2 (Fig. 8c-f; Plate 1a and c) mark a transition to much more quiet depositional conditions. The load structures in this interval suggest water-rich sediments and density contrasts between the white and black chert (or their precursors), the now white chert having been denser (Fig. 8d, Plate 1b).

The combination of subaerial and quiet subaqueous environments devoid of energy fluctuations in unit 2 would fit an interpretation in terms of a lagoonal or lacustrine environment in a low-relief area.

\subsection{BRC unit 3: Iron-oxide-rich sandstone-siltstone interval}

Geometry and large-scale structure: Unit 3 is poorly exposed, which makes the nature and the exact location of the contact with unit 2 difficult to establish over most of the area. The contact is generally taken above the uppermost, well-banded chert outcrop of unit 2. Thickness differences across the normal faults are less evident than in the underlying units. In the westernmost part of the area, a sub-unit of red, black and white banded chert appears within unit 3. Although exact measurement is difficult due to post-depositional faulting (De Vries et al., 2006a), the thickness of the unit as a whole increases from $\sim 135 \mathrm{~m}$ in the east $(\log \mathrm{E})$ through $\sim 300 \mathrm{~m}$ in the centre, to an estimated $800 \mathrm{~m}$ in the west (Figs. 1 and 4). In the central part of the area (at the location of $\log$ B, Figs. 1 and 5), the exposure is limited to a few isolated slabs of banded chert that have been tectonically rotated. The slabs are metres thick, up to tens of metres wide, locally folded on a decametre-scale (Fig. 5), and composed of planar-bedded cherts identical to those in the upper part of unit 2. Their surfaces are locally coated with Fe-oxide.

Facies: Unit 3 is iron-oxide-rich, and much less silicified than the underlying and overlying units. The type section of unit 3 was taken at $\log$ location E (Figs. 1 and 4; detail in Fig. 9), the only place with relatively good exposure of the entire unit 3 . It is composed of stacked $\sim 20 \mathrm{~m}$ thick sequences (Fig. 9a and b). Towards the east the succession is laterally cut by a N-S fault (Fig. 9b) that delimits a partial collapse structure in the southern limb of the Granville Syncline (De Vries et al., 2006a).

The grain size within the sequences coarsens upward from $\mathrm{cm}$ scale alternations of banded sandstone-siltstone and chert to better sorted, even-laminated and, in the upper successions, cm-scale (wave-) rippled sandstone (Fig. 9c). The latter beds are abruptly overlain by upwards increasingly pronounced, coarse, silicified breccia (Fig. 9b). Breccia clasts are generally thin and platy, with angular to round edges in an edgewise fabric.

Westwards, the quality of the exposure deteriorates rapidly. Nevertheless, both low-angle aerial photographs and field observations reveal important discordant structures in this interval. The rhythmic, sequential architecture at $\log$ location $\mathrm{E}$ is interrupted by an irregular, upwards widening, discordant structure terminating upwards in funnels that cross the sedimentary layering and breccia layer 5 (Fig. 9a); at this point the breccia layer and the underlying chert are turned 'upwards', i.e. upwards with respect to the bedding in its original horizontal position. The breccia layer wedges out away from this point towards the east (Fig. 9b). The discordant structure is filled with folded, extremely iron-oxide-rich shale, sandstone and chert (Fig. 9d), which, apart from their iron-oxide content, are of the same facies as the sequences which have been disrupted. These sediments could equally well be described as an iron pod or a gossanous feature wherein the sediments, though folded, preserve a sub-vertical dip (Fig. 9d).

The facies of unit 3 at $\log$ location $E$ is not representative for the entire unit. Towards the west, at $\log$ location $\mathrm{B}$, the top of the unit contains coarser-grained, well-sorted and well-rounded Feoxide-rich quartz arenite, with metres-wide trough cross-bedding (Fig. 10a). Further westwards beyond $\log$ location A, the chert facies grades into Fe-oxide-rich shale with intervals of even-laminated chert.

Sedimentological interpretation: The decametre-scale rhythmicity observed in unit 3 in $\log \mathrm{E}$ is similar to that in unit 2 . Although the depositional environment was relatively quiet at this location, the primary structures in unit 3 indicate more variation in energy level than those in the upper part of unit 2.

The coarse breccias at the top of the $\mathrm{CU}$ sequences, on the contrary, indicate sudden, aberrantly high-energy conditions. The thin, flat components of the breccia suggest that they were of local origin and their often edgewise fabric testifies of a 'heaping up' mechanism, as is known from storm-deposited flat-pebble conglomerates in carbonate rocks (Purdy, 1963; Myrow et al., 2004). The geometric relationship between the breccias and the funnel-shaped structures with iron-oxide-rich sediments however suggests that at least here the breccia was not generated by storm events but by explosive hydrothermal action. Geyser-like eruptions may have blown away the sediment cover and turned-up the rims of the vent. Around the vent, the sediment fragments would have been deposited sideways into a breccia cone, as is suggested by the observation of the rapid thickness decrease of the breccia layer away from the vent. At the same time, an explosive vent can be expected to have exposed the sediment-water interface to the forceful expulsion of a mixture of unconsolidated sediment and iron-rich fluids, as the observation suggests. The fold axes of this sediment lie generally within the bedding plane (Fig. 9d), which means that they were sub-horizontal during such an expulsion and mixing process. Brecciation due to hydrothermal eruption is an obvious mechanism 

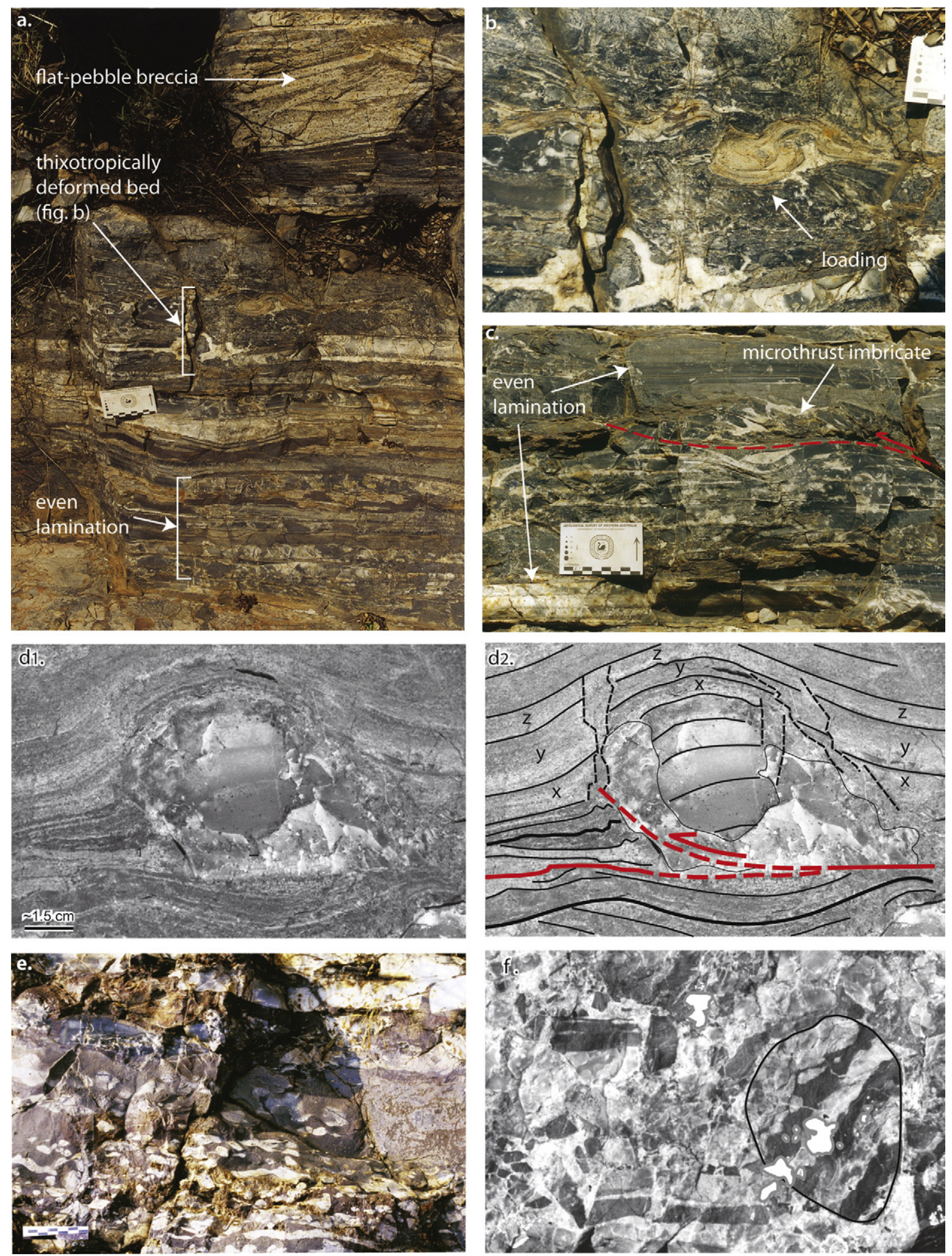

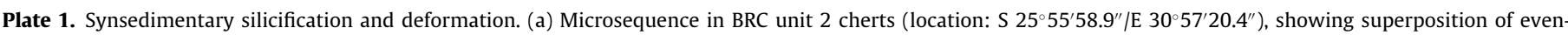

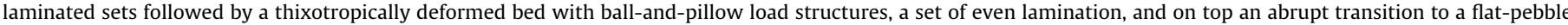

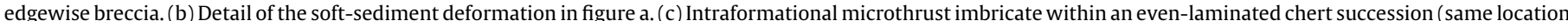

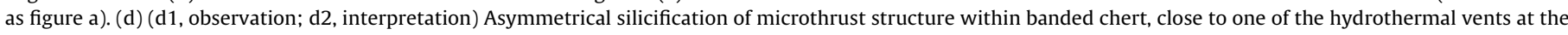

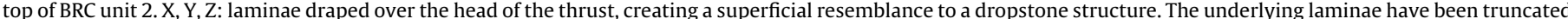

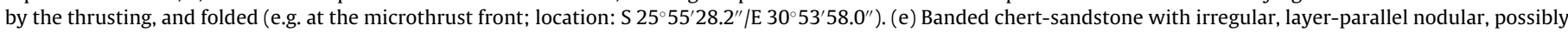

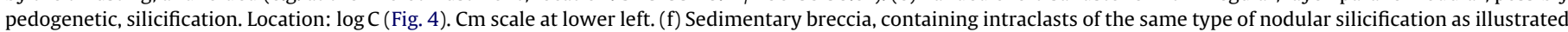

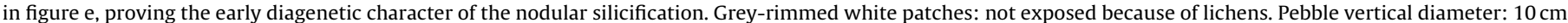

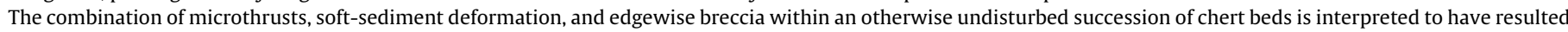
form seismic/hydrothermal explosive events (cf. Fig. 8d-f). 

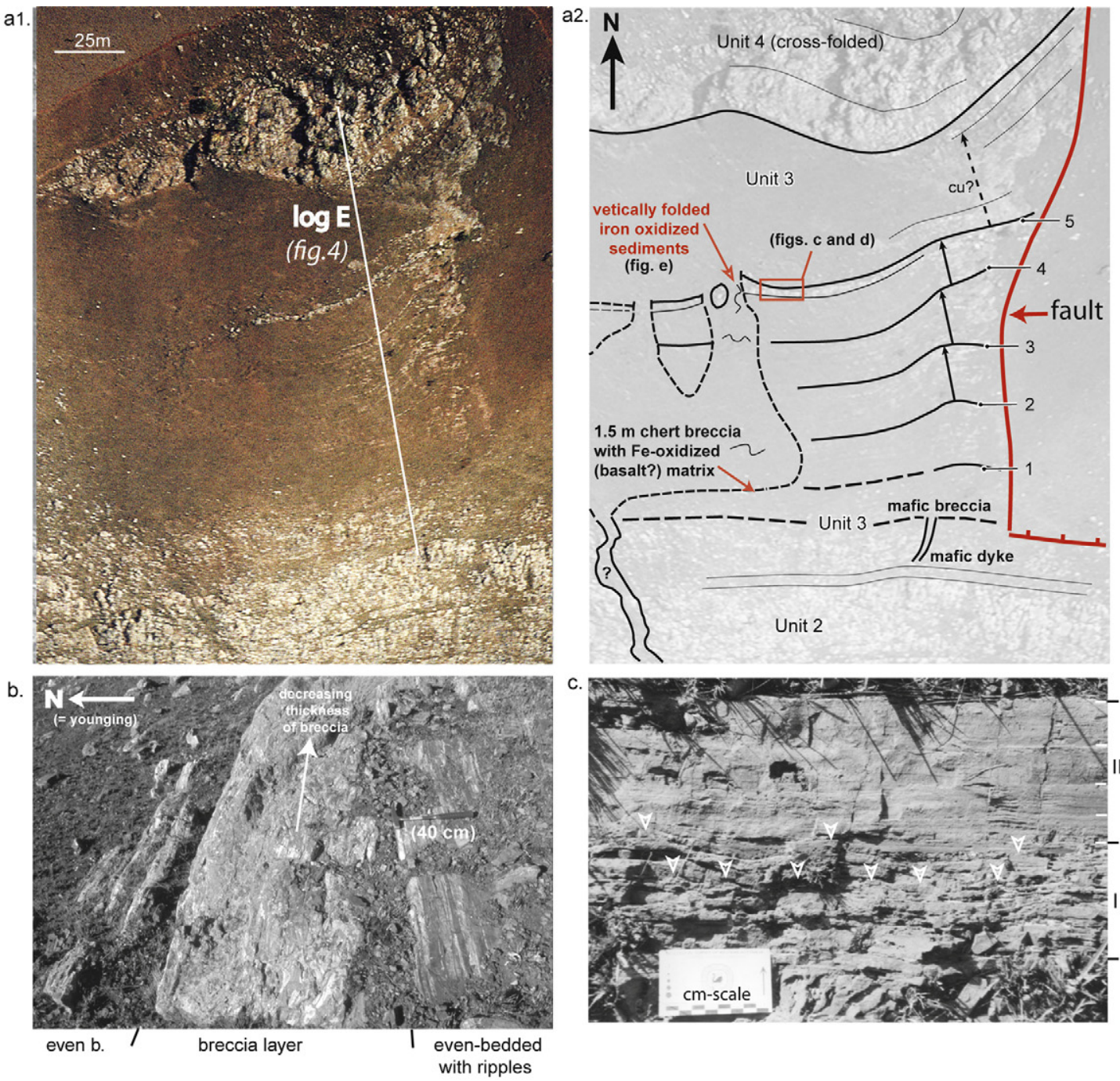

d.

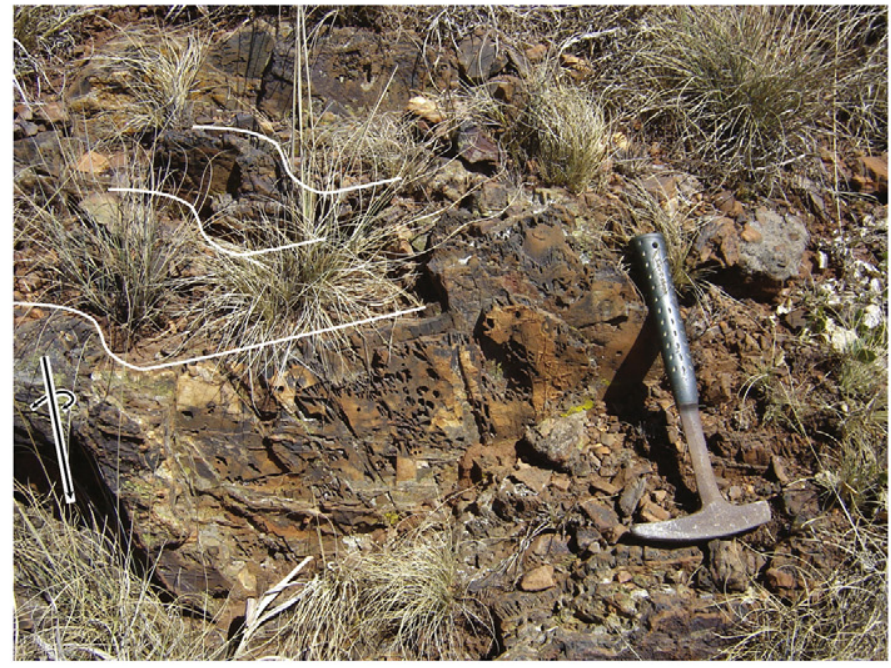

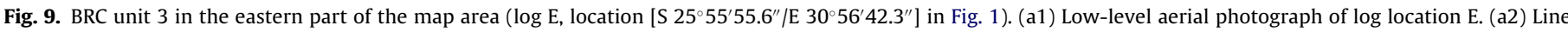

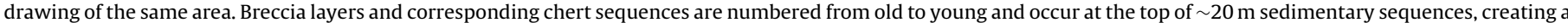

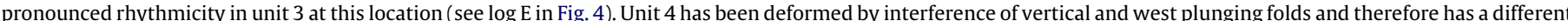

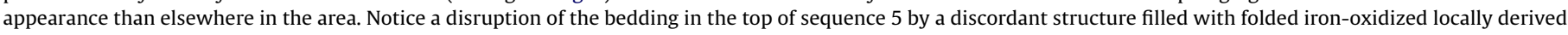

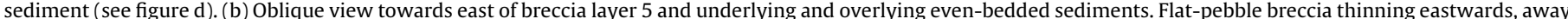

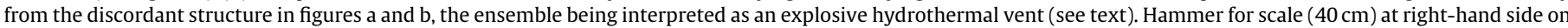

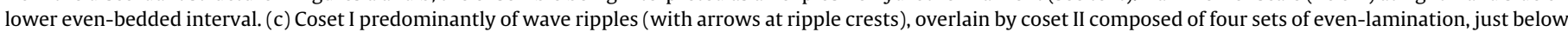

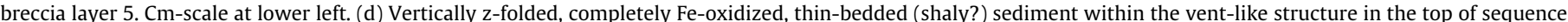
5 , location indicated in figure a2. The subvertical fold axis is indicated in the lower left corner. 

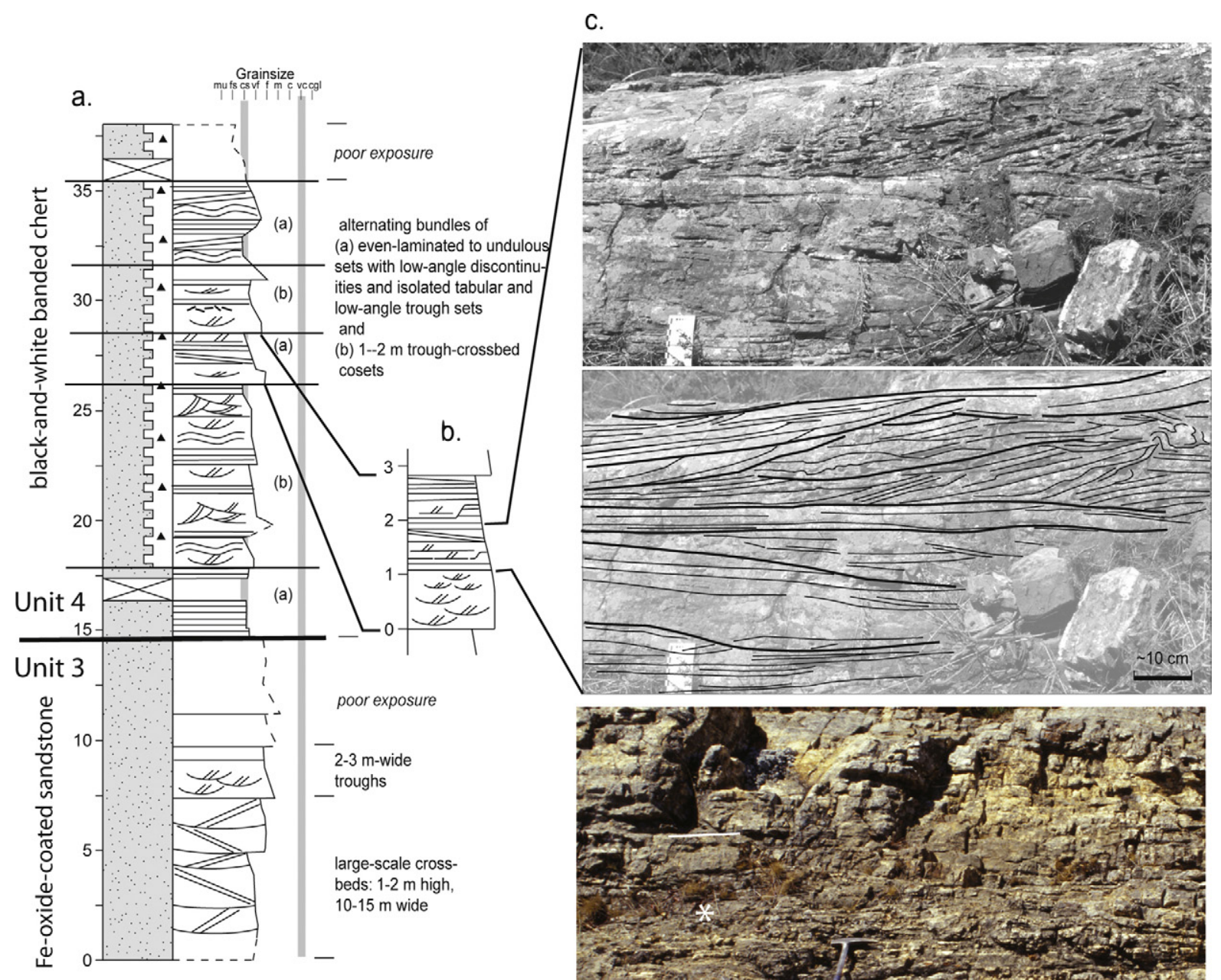

e.

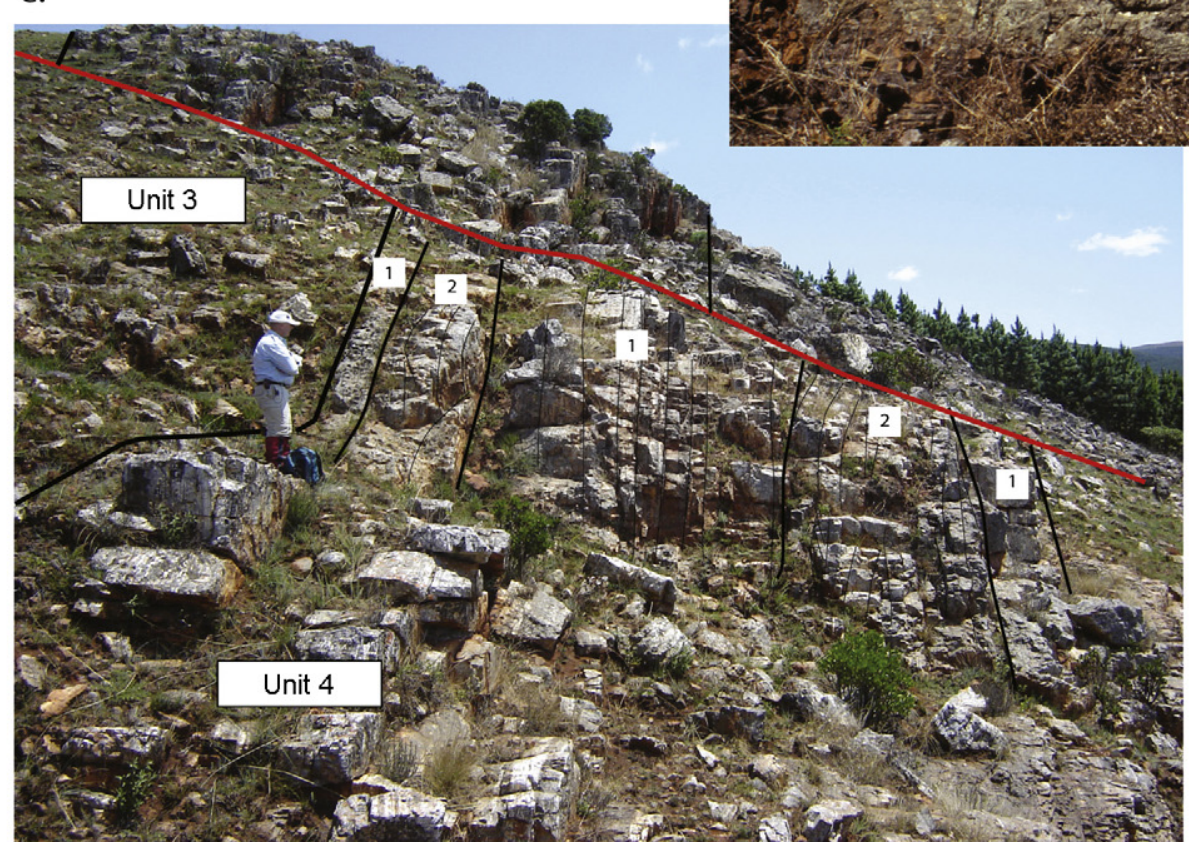

1: even-laminated chert:

foreshore (swash zone);

2: trough cross-bedded chert: shoreface (breaker zone)

Fig. 10. (a) Simplified sedimentary log through BRC unit 4 at log location B. For location (S $\left.25^{\circ} 55^{\prime} 12^{\prime \prime} / E 30^{\circ} 53^{\prime} 21^{\prime \prime}\right)$ see Figs. 1 and 5 , legend in Fig. 3. (b) Detail of the sedimentary succession around $27.5 \mathrm{~m}$. (c) Photograph and line drawing illustrating part of the succession shown in figure b. (d) Hummocky cross-stratified chert $\left({ }^{*}\right)$ between trough cross-bedded cherts. The hummocky cross-bedding represents a storm phase, the underlying coset consists of short wave-length trough cross-laminated sets and is interpreted to represent surf zone stratification. (e) Overview of the lower part of BRC unit 4 on top of unit 3, showing an alternation of even-laminated [1] and trough cross-bedded [2] cosets. The location is some tens of metres east of log location $B$. 
to juxtapose the aberrantly high-energy breccias with sediments deposited under more quiet conditions. An important implication is that the regular occurrence of hydrothermally generated breccia at the top of the coarsening-up sequences suggests a relation between hydrothermal activity and sea or groundwater level variations (see below). The iron enrichment seems to have a direct relationship with fine-grained mafic dykes in the underlying unit 2 (Fig. 9a2).

The Fe-enrichment and the occurrence of iron pods is an issue very much under discussion in the Archaean geology of the Barberton area, in which the question is, whether the structures are Archaean or a much younger phenomenon (e.g. Lowe and Byerly, 2003, 2004, 2007; De Ronde et al., 2004). A full discussion of this problem is out of the scope of this article. Nevertheless, in Fig. 9 we give a clear-cut example of disruption, upturning and brecciation of the bedding related to a bedding-traversing body of completely Feoxidized up to BIF-like sediments folded with subvertical fold axes. Furthermore, in the entire geological setting, iron pods appear to be related to particular stratigraphical intervals (e.g BRC unit 3 and in the eastern part of the Buck Ridge also between units 1 and 2) that can be traced along both flanks of the Granville Syncline, a structure previously described in De Vries et al. (2006a). Observations such as those mentioned above point to a synsedimentary, i.e. Archaean, iron enrichment. On the other hand, later remobilisation of iron-concentrations of older age certainly cannot be excluded.

\subsection{BRC unit 4: Capping, silicified, cross- to even-laminated sandstone}

Geometry and large-scale structure: Unit 4 is best exposed in the central part of the map area ( $\log B$, Figs. 1 and 4 ), where the thickness is $\sim 20 \mathrm{~m}$. To the east, the outcrop is discontinuous (Fig. 1) because of deformation in the limb of the Granville Syncline (De Vries et al., 2006a). The base of unit 4 is taken where the lowermost outcrops of banded chert occur above the poorly exposed and less silicified Fe-oxide-rich sediments of unit 3. The thickness of unit 4 does not vary significantly along strike (Fig. 4). Normal faults offsetting unit 4 are post-depositional. The type section of unit 4 is the uppermost part of $\log$ B (Fig. 1; Fig. 10a-e).

Facies: Unit 4 consists of an alternation (Fig. 10a and e) of trough cross-bedded and even-laminated to undulose-stratified cosets (Fig. 10c). The even-laminated sets contain low-angle discontinuities and isolated dm-scale bars (Fig. 10c). The trough cross-bedded intervals have a wide range of sizes from several $\mathrm{dm}$ up to $2-3 \mathrm{~m}$, sometimes with a short wavelength with relative to the amplitude (Fig. 10d). The undulose stratification is at least partly hummocky (asterisk symbol $\left({ }^{*}\right)$ in Fig. 10d). Imbricate stacking of flat chert pebbles is occasionally observed in the high-angle cross-bedded intervals. Both eastward and westward dipping foresets occur.

Sedimentological interpretation: The abundant occurrence of low-angle discontinuities between the even-laminated sets and the trough and tabular cross-bed sets in the upper interval indicate relatively high energy conditions. The sedimentary succession of unit 4 can be compared to modern-day, wave-dominated beach and near-shore environments, in which swash and back-wash cosets (even-laminated) alternate with cross-bed sets of inlets and/or surf zones (trough cross-beds) and storm beds (hummocky stratification) (Harms et al., 1975). This is supported by the variable foreset orientations.

\subsection{The BRC: a regressive-transgressive succession near base level, controlled by extensional faulting}

Unit 1 was deposited under high-energy conditions, during pulses of sediment supply, probably pyroclastic surges. High energy and supply of sediment also characterise the lower part of unit 2, though with less primary volcanic influx. Both unit 1 and the lower part of unit 2 were deposited in shallow water, and occasionally experienced subaerial conditions. This reflects a regression after deposition of the underlying pillow basalts in the upper part of the Hooggenoeg Formation. The upper part of unit 2 was deposited in a low-energy, sheltered but subaqueous environment, probably under lagoonal or lacustrine conditions. The interpretation of a shallow-water environment for both units 1 and 2 is different than the interpretation of Tice and Lowe $(2004,2006)$, who explain the low-energy environment in the uppermost part of (what we call) unit 2 as having been deposited well below storm wave-base.

At log site E the energy conditions gradually increased during deposition of the successive coarsening upward (CU) sequences of unit 3 as shown by the increasing amount of current and wave structures in their tops. The alternation of even-laminated and cmscale rippled sandstone suggests a still relatively low energy in the depositional environment.

A further interpretation of this badly exposed unit 3 is difficult and depends also on its position between the top of unit 2 and the better exposed uppermost unit 4 . For the latter unit we concluded from the content of primary structures to a littoral environment (shoreface). The entire succession thus shows an evolution from the quiet lagoonal conditions at the top of unit 2 via the still low, but upwards increasing energy conditions of unit 3 , into a coastline represented by unit 4 . We tentatively consider the $\mathrm{CU}$ rock succession of unit 3 at $\log$ location $\mathrm{E}$ as a protected beach or a washover fan environment between a lagoonal or lacustrine environment below and a barrier beach on top. In other words, $\log \mathrm{E}$ might indicate a gradual transgression, which culminated in the littoral environment of unit 4.

Relative sea-level rise thus would already have started during deposition of the upper part of unit 2 with the rise of the groundwater level to create lacustrine or lagoonal conditions. In this respect, the $20 \mathrm{~m}$ rhythmic pattern of deposition in units 2 and 3 could well be related to higher order, orbitally-forced sea or ground water level fluctuations. The next step in this line of reasoning is that if the breccia had a hydrothermal vent origin, these explosive hydrothermal emanations must have been linked to these water level fluctuations.

The sediments of the BR-vsc consist mainly of locally derived volcanic and volcaniclastic material. The composition of the sediments in the scour-and-fill structures of unit 1, the lithology of the fragments in the thin breccia beds within these structures and the conglomerates adjacent to the normal faults that controlled sedimentation, all support this conclusion. The scour structures do not mark a regional unconformity. Local unconformities, however, did form in uplifted footwalls of the faults (cf. Nijman and De Vries, 2009). Apart from these local unconformities, there is neither evidence for erosion of the underlying pile of mafic and ultramafic rocks, nor for sediment supply from granite or gneiss terrains in the hinterland. This lack of evidence for regional erosion of older units indicates that there was probably no significant subaerial relief in the area around 3.4 Ga ago.

Both the block motion (west-block-down normal faulting) and the general east to west facies change correspond to an overall change from basin margin in the east to basin centre in the west (cf. Nijman and De Vries, 2004). The eastward (i.e., towards the basin margin) mega-foresetting of the volcaniclastic sediments of unit 1 in particular, suggests a volcanic source somewhere in or near the centre of this basin.

\section{Sedimentology of the Kittys Gap Chert}

\subsection{Stratigraphical subdivision, geometry and structural features}

Fig. 2 gives an overview of the thickness, varying from $35 \mathrm{~m}$ (footwall) to $250 \mathrm{~m}$ (hanging wall), and the distribution of the sili- 
a.

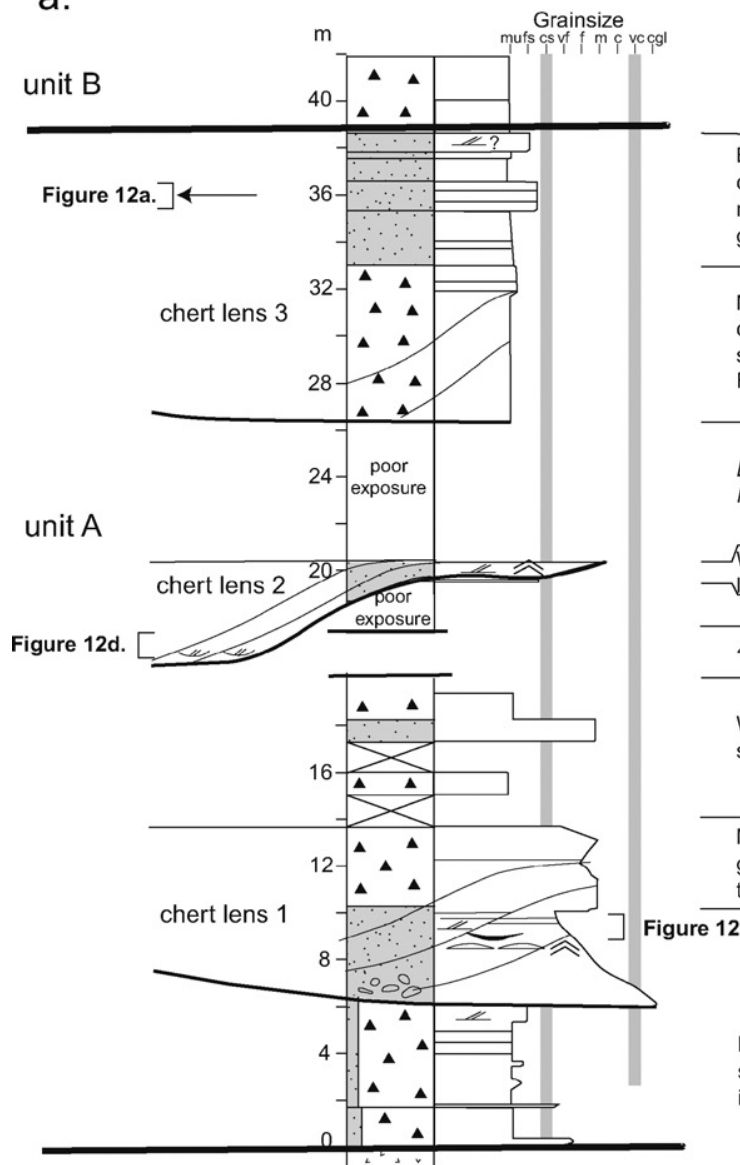

b.

Brownish weathered, less silicified compared to over and underlying rocks. In places silty. Finer-grained: green chert, occ. with small black

Massive light green chert. Full of chert, occasional quartz, vein stockworks up to brecciation.

Fragments then show jig-saw fit

Laterally to the west, felsic intrusives. Interval may partly be sedimentary.

Westwards thickening fining-upward Lens comparable to lens 1

$40 \mathrm{~m}$ of probably intrusive, mafic rock

Where exposed: glassy, structureless

Massive black chert, ghosts of granular texture. Massive, $15-40 \mathrm{~cm}$ thick beds.

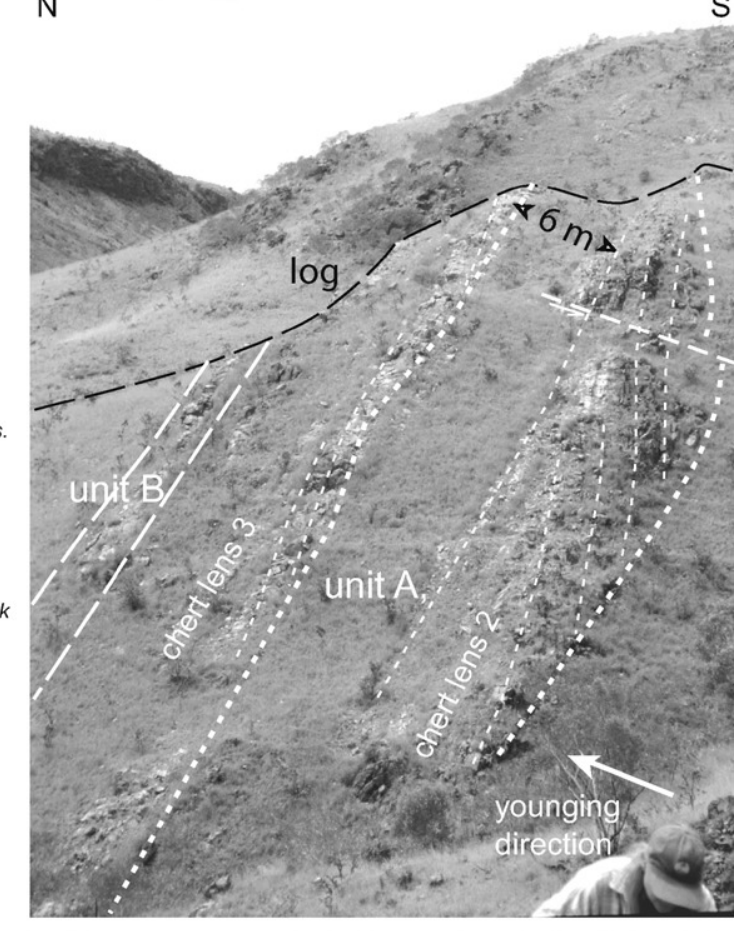

Poorly exposed grey-white chert. No structures in major part of the interval

d.

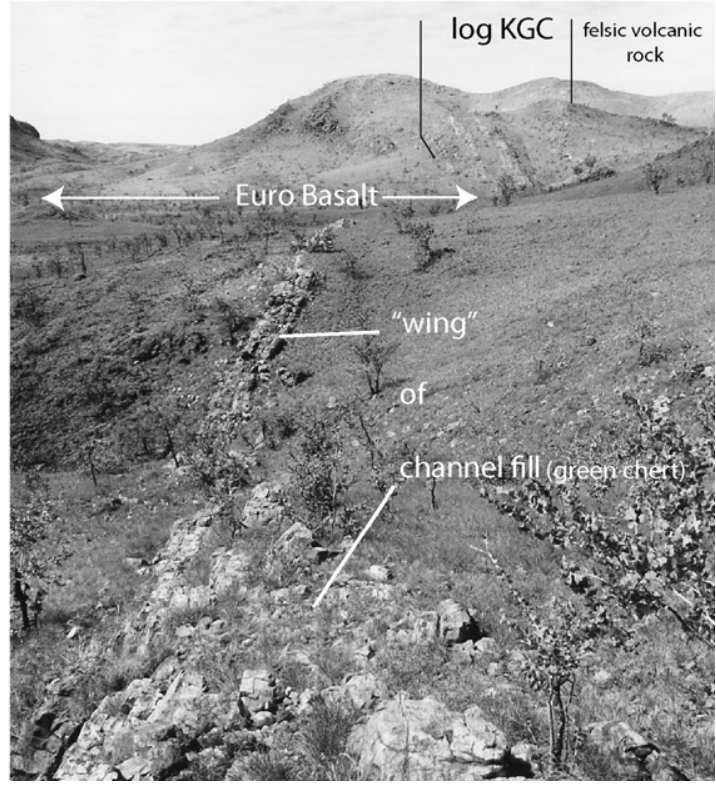

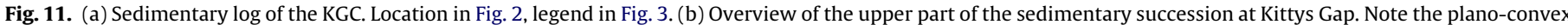

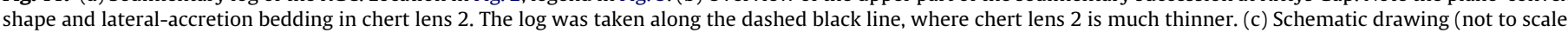

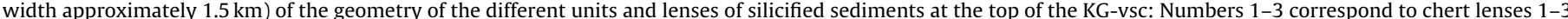

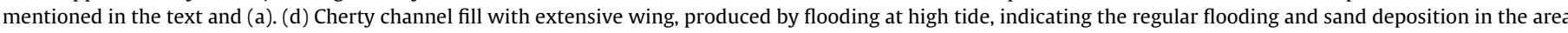

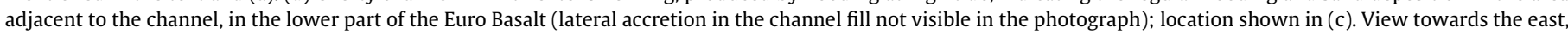
younging to the left. In the background the KGC log location of (a).

cified sedimentary succession (KGC; sedimentary log Fig. 11a and b) at the top of the KG-vsc over a length of $\sim 5 \mathrm{~km}$. Three units are distinguished (Fig. 11c): units A and B, both composed of chert and recorded in detail in the sedimentary $\log$, and unit $C$, a rapidly eastward thickening interval of shale and fine-grained sandstone and minor chert, exposed east of the log. The geometry of the KGC has partly been modified by igneous rocks, which appear as yellowish, strongly weathered rocks at the $\log$ location within unit $A$, and as quartz-phenocryst-bearing rock further eastward between units $A$ and $\mathrm{B}$.
For the general geological setting of the KGC at the top of an array of syn-depositional normal faults, the reader is referred to Van Kranendonk et al. (2001) and De Vries et al. (2006b).

\subsection{KGC units $A$ and $B$}

Geometry and large-scale structure: Unit A forms the bulk of the KGC. It is characterised by en echelon stacked, tens of metres wide, plano-convex and cross-bedded chert lenses surrounded by evenbedded chert (e.g. Fig. 11b and c). At the log location, three of these 
chert lenses are exposed (Fig. 11a-c). The lower two are separated by a $40 \mathrm{~m}$ thick, poorly exposed, probably intrusive interval (see above).

Unit B is relatively thin ( $\sim 10 \mathrm{~m}$ at the log location) and laterally traceable as a sheet along the top of the KGC. Where it overlies one of the chert lenses of unit $A$, as is the case at the log location, the exact boundary between units A and B is difficult to identify because of the intense silicification.

The overlying Euro Basalt is pillowed at many places, and an exposure some tens of metres above the KGC contains hyaloclastic basalt breccia and columnar jointing. At the same level within the Euro Basalt, relatively thin elongated chert lenses $(\sim 1.5 \mathrm{~m}$ thick, length/width ratio $>40$; Fig. 11d) occur with well-developed channel-fill characteristics and lateral-accretion bedding, indicating that the transition from unit B to the overlying Euro Basalt is more gradual than apparent at first sight.

Facies: Chert lenses 1 and 2 (Fig. 11) both consist of finingupward, silicified, black and white banded sedimentary rocks, with a well-preserved granular texture and primary sedimentary structures at several scales. These include up to $5 \mathrm{~m}$ high low-angle oblique bedding (Fig. 11b), upwards grading from mega-trough cross-bedding at the metre-scale (Fig. 12d), to small-scale ripples and undulous to even bedding at the top (Fig. 12a and b).

Chert lens 1 contains several 1-7 cm layers of black pebble conglomerate with sandy matrix along the base. The conglomerate overlies poorly exposed silt-sized chert beds. Away from the log location, the pebbles tend to float in the matrix and elongated banded chert pebbles are in places in an originally upright position. These conglomerate layers form the base of fining-upward oblique beds with ripples, flaser-linsen structures and undulating lamination in the upper part (Fig. 12a and b).

The $6 \mathrm{~m}$ thick (measured outside the log trace) chert lens 2 is quite similar to that of lens 1 described above (Fig. 11c)., i.e. similar oblique beds with a fining upwards trend from basal conglomerate to sediment with abundant small-scale sedimentary structures such as current and wave ripples. As in chert lens 1, the capping fine-grained sediment is heterolithic and contains, amongst others, $1 \mathrm{dm}$-spaced wave ripples.

Chert lens 3 shows another example of lateral accretion bedding, best visible west of the log profile. In some of the extremely fine-grained chert layers, occasionally, pitch-black mm- to $\mathrm{cm}$ outsized grains (or diagenetic colourations) are present. Owing to the crypto-crystalline textures of the rock it is unclear if the black material once formed distinct grains. There are no indications of a coarser-grained texture in the pale green chert prior to silicification. The unit is intensely veined, with translucent veins in the lower part, and black chert vein networks in the upper part. Along strike, the colour of the upper unit varies between pale green and glassy black. The latter is usually observed in places where the original, often granular, texture is almost completely obscured due to the thorough silicification (except on some weathered surfaces).

Two hundred meters west of the log location, units A and B contain coarse breccia layers and pods. The breccia fragments are rounded to angular, black, banded chert, up to $15 \mathrm{~cm}$ long, surrounded by a pale green chert matrix (Fig. 11b in Nijman et al., 1998b). The lower breccia layers are matrix-supported. Upwards, the percentage of matrix decreases and the breccias become clastsupported. The breccia layers are overlain by approximately $2 \mathrm{~m}$ wide, $80 \mathrm{~cm}$ high low-angle trough fills. The fills are composed of very fine-grained, finely laminated sediments, with abundant $\mathrm{cm}$ scale ripples in the upper layers. Fig. 12a and c show some of the variation at that location.

Current directions: Reliable measurements of palaeocurrent directions are sparse, and insufficient to plot, but those documented at least point to bimodality of the currents. In chert lens 1 , imbrication of pebbles in the basal conglomerates suggests an ENE $\left(056^{\circ}\right.$, $103^{\circ}$ ) current direction. Ripple foresets confirm a dominantly eastward current, while reactivation surfaces suggest the activity of counter-currents (e.g. Fig. 12a). Associated climbing ripples, too, are oriented westwards. The channel fills are visible in oblique cross-section in valley incisions and correspond to the dominant east-west cross-bed orientations.

Palaeocurrent directions in chert lens 2 are dominantly to the west and south-west. Opposing current directions were also observed (dip directions of foresets after correction for tilt: $090^{\circ}$; $270^{\circ}$ ).

In chert lens 3 and unit $\mathrm{B}$, indications for a palaeocurrent direction are absent at the log location, while $200 \mathrm{~m}$ to the west ripple foresets indicate current directions dominantly to the E-SE (dipdirections of foresets after correction for tilt: $088^{\circ} ; 116^{\circ} ; 152^{\circ}$ ). In the sandstone-siltstone-shale succession $750 \mathrm{~m}$ east of the log location, palaeocurrent directions both to the $\mathrm{E}$ and $\mathrm{W}$ to SW were found (Fig. 12a and c).

Sedimentological interpretation: The plano-convex, finingupward chert lenses with oblique bedding in unit A of the KGC are interpreted as en echelon stacked channel fills with lateral-accretion bedding and conglomerate lags. Their primary sedimentary structures indicate relatively high current velocities, and climbing ripples indicate a relatively large sand supply (cf. Ashley et al., 1982). Flat chert pebbles incorporated in the sediments in a vertical position are most likely storm-related ('edgewise conglomerate', see however also the sedimentological interpretation in Section 2.4). Heterolithic sediments at the top, lateral of, and below the channel fills are the lower-energy representatives of an environment with evidently rapidly fluctuating energy level. These observations, combined with a wide range of structures such as reactivation structures, flat-and-channel architecture, bimodal current directions (even though statistically insignificant) together offer good evidence for a clastic, intertidal environment (cf. Nio and Yang, 1991). The "wing" attached to this channel (Fig. 11d) is also indicative of an intertidal environment. Indeed, in the intertidal domain ebb currents tend to concentrate within the tidal channels and maximum flood currents occur when adjacent tidal flats have been flooded and thus sand is spread as wings over the adjacent tidal flats (Cuevas Gozalo and de Boer, 1991; De Boer, 1998). Fig. 12d moreover suggests neap-spring cyclicity (cf. Visser, 1980; de Boer et al., 1989). Such structures resemble similar tidal deposits in the 3.2 Ga Moodies Group of the Barberton Greenstone Belt (Eriksson and Simpson, 2000).

The lag deposits, as well as most of the overlying sediments, consist of reworked volcanic and clastic material. Exceptions are a layer with embedded $\sim 0.5 \mathrm{~cm}$ diameter pumice fragments (Westall et al., 2006) in a heterolithic interval of chert lens 1 (Fig. 12b) and, possibly, some of the even-laminated fine-grained layers, which may be primary ash-fall deposits.

Unit B is similar to unit A in that they both have a heterolithic character and contain wave- and current-rippled beds. The environment of deposition of unit $B$ is different, however, in the absence or paucity of channels and in the presence of homogeneous, massive and, in places, finer-grained and better-sorted cherts with a sheet geometry. The latter facies points to a well-sorted, wavewashed or wave-deposited sediment, reflecting a change from a very shallow tide-dominated to a more wave-dominated environment in which sediments are spread laterally.

The exceptionally coarse breccias in units A and B west of the log (cf. Nijman et al., 1998b) indicate abrupt, local differences in energy conditions in what we interpret as a tidal lagoon. Angularity, geometry, and absence of an erosional base indicate that the breccia is unlikely to be part of a channel fill. Their occurrence in an area with a high density of black chert veins in the underlying lava and volcaniclastic deposits of the KG-vsc (Nijman et al., 1998b) suggests that the breccia bodies are related to explosive hydrothermal activ- 

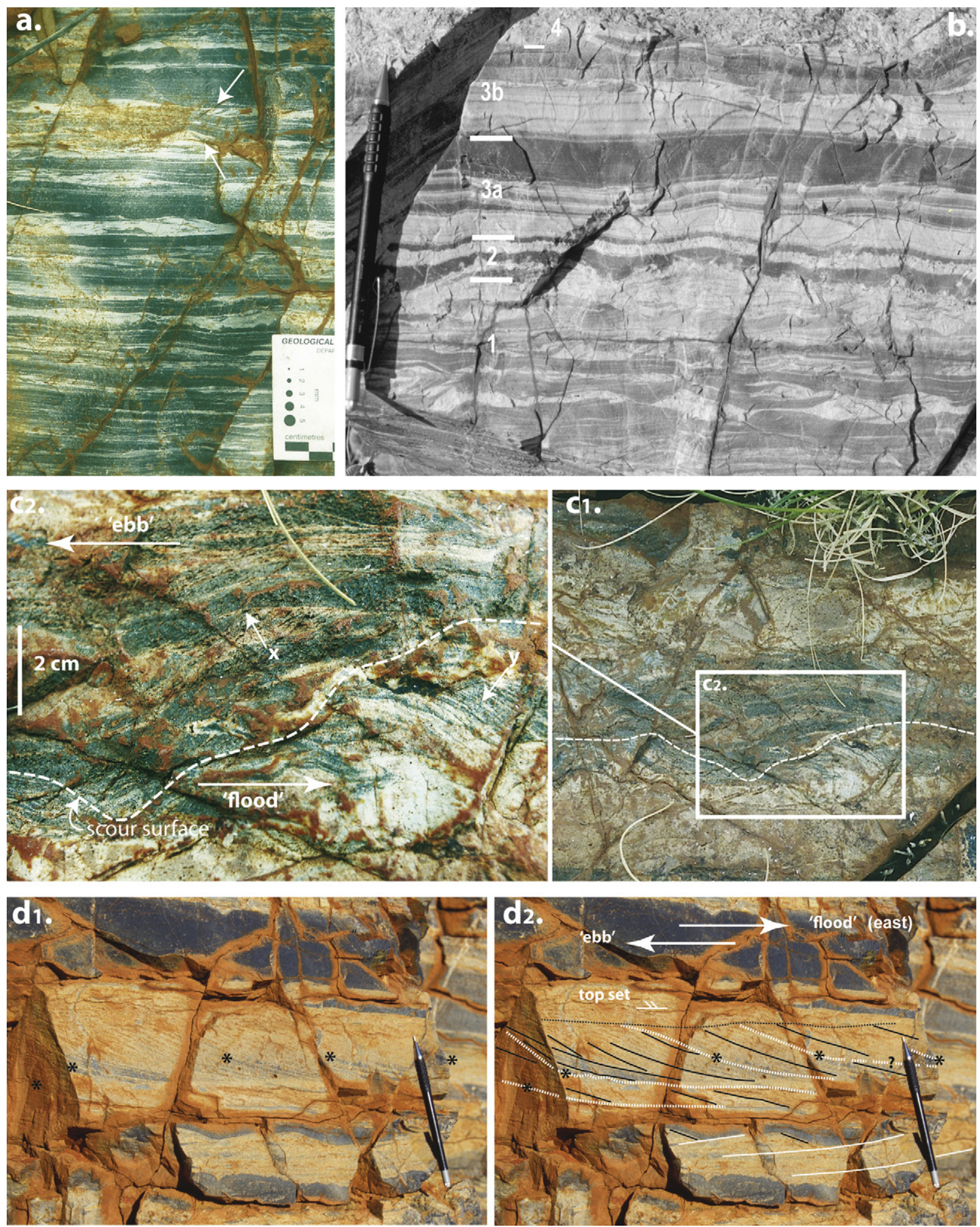

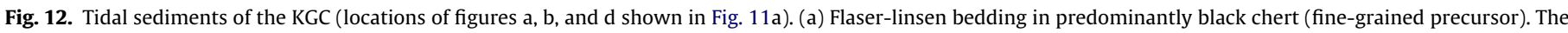

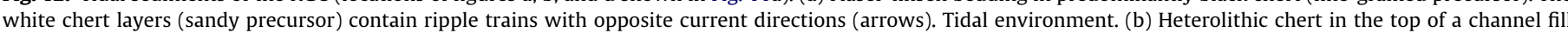

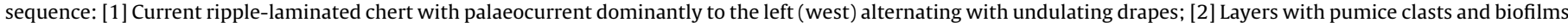

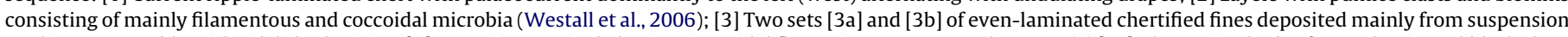

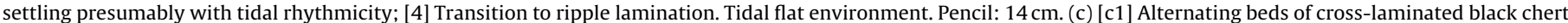

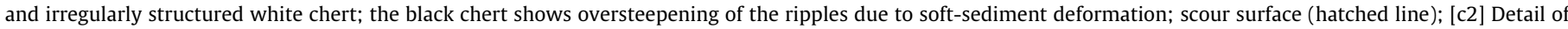

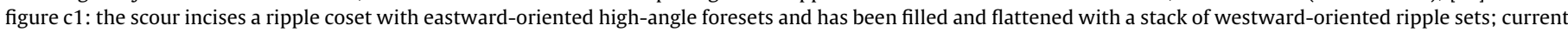

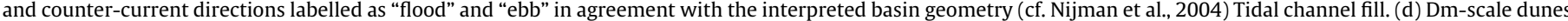

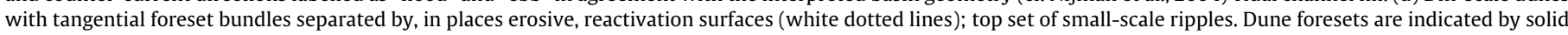

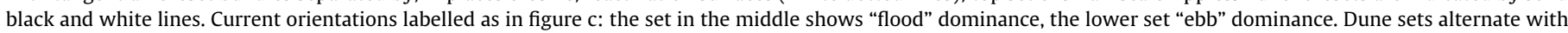
finer-grained drapes. Tidal channel fill. Pencil: $14 \mathrm{~cm}$. 
ity within the wave and tide-dominated sedimentary environment of the KGC.

\subsection{KGC unit $C$}

Geometry and facies: To the east of the log location an eastwards thickening (up to $\sim 210 \mathrm{~m}$ ) wedge of shale and tuff emerges from a stratigraphic level between units A and B (Figs. 1 and 11c). The shale contains illite and subordinate kaolinite, the latter postmetamorphic (H. Kisch pers. comm., 2010), and therefore probably due to later surface weathering. The deposits are dominated by even bedding and even lamination. Occasionally, sandier and partly silicified beds fine upwards, show climbing ripples and small-scale convolutions and load structures, all characteristic of the typical Bouma-sequence in turbidites. Locally, isoclinal, dm-scale folds occur in the shales.

Sedimentological interpretation: Unit C was deposited mainly by suspension settling. While current strength diminished drastically relative to the underlying unit, mass-flow activity evidently increased as indicated by the Bouma-type sequences (turbidites, tempestites; cf. Myrow et al., 2002) and collapse structures. This facies is restricted to the hanging wall block of one of the major controlling growth faults of the KG-vsc fault array. Along this particular fault, tectonic subsidence could not be completely compensated by sedimentation, which led to the development of a local slope within the otherwise shallow water environment. Tiny mass flows generated on this slope by the growth fault activity and storms were directed towards the developing fault scarp.

This rather rare example of underfill and burial of the sediment in water slightly deeper than elsewhere in the KGC environment, and close to one of the leading growth-faults, may have caused a lesser silicification than in units A and B. A similar situation has been found east of Bamboo Creek Mine at the same stratigraphic level and in a comparable extensional setting (Nijman et al., 1998b).

\subsection{The KGC: a fault controlled tidal flat environment at an extensional basin margin}

The architecture of the KG-vsc does not allow such clear-cut conclusions on relative sea level trends as can be drawn for the BRvsc. The KG-vsc does compare with the BR-vsc in its superposition of chert on felsic volcanic rocks and these in turn on subaqueous pillow basalts. The overall pillowed character of the overlying Euro Basalt equally points to a subaqueous environment, but the above-mentioned exposure of hyaloclastic breccia and columnar jointing also indicates a subaerial character of the basalt flow in question at about zero water level. This zero depth interpretation is corroborated by the enclosed channel fill with lateral-accretion bedding and extensive wing deposits (Fig. 11d), indicative of intertidal meandering flows, thus fitting well between the KGC and the pillowed parts of the Euro Basalt. This implies that within the basal part of the Euro Formation the point of maximum regression had been reached. This leads to the assessment of a possible regressive trend starting in the underlying pillow basalt of the Apex Basalt via the tidal deposits of KGC-unit A into a possibly inner shoreline position of unit $\mathrm{B}$, and then towards maximum regression within the Euro Basalt. No indications exist for a transgressive top like the one present in BRC-unit 4.

The above interpretation of the sedimentary environment of the KG-vsc and its sedimentary geological setting is supported by the correlation with massive well-sorted and well-rounded silicified sandstones at the level of the Panorama Formation at Doolena Gap, $\sim 30 \mathrm{~km}$ to the west in the Coppin Gap Belt ("P-unit" in Fig. 8 in Nijman et al., 1998b), which may represent the outer coastline of the tidal lagoonal complex described above. In the opposite direction, i.e. eastwards, the KG-vsc wedges out south of Bam- boo Creek Mine (Fig. 2 in Nijman et al., 1998b). This suggests the change towards an area of non-deposition, i.e., an emersion surface inwards from the tidal complex. Such an interpretation matches with a position of the KG-vsc at the margin of a major extensional basin that persisted during deposition of the major part of the Palaeoarchaean Warrawoona Group (cf. Nijman and De Vries, 2004).

KGC sedimentation was controlled by growth faulting. The influence of syndepositional faulting on the KG-vsc sediments is most evident from the wedge-shaped siltstone-sandstone-shale interval in unit C. Growth faulting started in the west and proceeded eastwards as is visible from the progressive deformation of the growth faults in the opposite direction (Fig. 2; cf. Nijman and De Vries, 2004).

The sediments of the KG-vsc seem to consist mainly of locally derived volcanic detritus and chert. The products of volcanism and hydrothermal activity were either incorporated in the sedimentary succession directly, or reworked and re-deposited soon after primary deposition. There is no evidence for the erosion of rocks below the KG-vsc, or of older granitoid complexes. This lack of evidence for erosion indicates that there was no significant subaerial relief in the Kittys Gap area at the time of deposition of the KGC.

\section{Syn- to post-sedimentary, deformational and diagenetic effects in the BR-vsc and KG-vsc sediments}

Heterogenous silicification has strongly influenced the original sedimentary fabric and structure of the BR-vsc and KG-vSC sediments (e.g. Plate $1 \mathrm{~d}$ and f), thereby complicating the interpretation of their environments of deposition. Another disturbing factor is the intraformational deformation such as brecciation and soft-sediment deformation (Plate 1a and b, Fig. 8f).

Within layers, irregular silica fronts have been formed independently of the original sedimentary bedding and structures. For the concentric banding at right angles to the bedding in iron-rich cherts of the BRC and Fig Tree Group, and interpreted as mudpool structures by De Wit et al. (1982) and De Ronde et al. (1994), we follow the interpretation of Lowe (1999) that these structures are diagenetic and should be considered Liesegang Bands (e.g. Varghese and George, 2004 and references therein). They appear to result from discontinuous Fe-oxide precipitation around nuclei in porous sediment (e.g. sandstone), often due to weathering. We found the same structures also with silica instead of iron-oxide bands (Fig. 8f) and relate them to ongoing silicification processes within the cherts.

The observed abrupt intraformational disturbances within otherwise quietly deposited sediments such as intraformational brecciation (Fig. 9b, Plate 1a and f), thixotropical (soft-sediment) deformation (Fig. 8d, Plate $1 \mathrm{a}$ and b), intraformational thrusting (Plate 1c and d), and normal faulting (Fig. 8f), can be produced by a variety of processes. An important trigger for such structures in a growth-faulted setting are earthquakes, which means that they could be seismites (cf. Montenat et al., 2007; Mazumder et al., 2009). Another effective mechanism could have been pressure build-up and explosive fluid release in hydrothermal systems at local high temperatures.

Timing of the silicification: Diagenetic structures can only give information about the environment of deposition if diagenesis occurred very early and involved repeated cycles of sedimentation and lithification, as is well known from present-day carbonate environments. Pebbles and fragments of banded chert containing silica fronts and irregularly silicified sediments are incorporated into breccias in the same sedimentary succession, indicating that this type of heterogeneous silicification must have occurred during deposition of the sequence, prior to the incorporation of the fragment in the breccia (Plate 1f). Similarly, the angular 
and thin fragments of (now silicified) flat-pebble breccia indicate that already silicified layers were broken up and the fragments re-deposited in the immediate vicinity. The same holds for the combination of intraformational deformation and silicification seen in Plate $1 \mathrm{~d}$. It indicates that silicification was a multiphase process of which at least the first stages were synsedimentary. On the microscale, Westall et al. (2006) noted that colonies of microorganisms around individual particles of protoliths were rapidly silicified, thus indicating very early diagenetic silicification.

Origin of the silica: Tracing of the origin of the silica responsible for the thorough silicification of the BR-vsc and KG-vsc sediments is beyond the scope of this study. There are indications that the silicification of the BR-vsc and KG-vsc sediments was, at least in part, related to hydrothermal systems that were active in those areas during and immediately after deposition of the sediments (cf. De Vries, 2004; Orberger et al., 2006; De Vries and Touret, 2007; Hofmann and Harris, 2008). In addition to a magmatic silica source, a large part of the silica may have originated from seawater saturated with respect to Si (Van der Boorn et al., 2007), which circulated through the sedimentary pile due to the activity of hydrothermal systems. It has been suggested that the Si-content in Archaean seawater was much higher than today, since the siliceous organisms that buffer the silica concentrations in the present-day oceans did not exist yet (e.g. Holland, 1972; De Ronde et al., 1997).

\section{A comparable volcano-sedimentary complex elsewhere in the Pilbara: The North Pole-vsc}

In their sequential architecture, shallow environment of deposition, fault control and hydrothermal veining, the BR-vsc and KG-vsc resemble, to a large extent, the $\sim 3.49$ Ga old North Pole volcano-sedimentary complex (NP-vsc) of the Dresser Formation on the eastern flank of the North Pole Dome (East Pilbara, Australia; Nijman et al., 1998a; Van Kranendonk, 2000; Nijman and De Vries, 2004). The NP-vsc differs from the two complexes described here in the absence of felsic volcanic rocks, the absence of shale and the presence of abundant barite.

\section{Conclusions}

1. The geological settings of the BR-vsc (Barberton Greenstone Belt, South Africa) and KG-vsc (Coppin Gap Greenstone Belt, East Pilbara, Australia) are well comparable. The geometry of the vsc's and of the sedimentary successions at their top, as well as the local facies distribution within the successions, were controlled by syndepositional normal faulting, responsible for pronounced and abrupt thickness changes. The syndepositional faulting was also responsible for the formation of intraformational unconformities in the footwalls of fault blocks in the BRC and for the preservation of only slightly silicified mass-flow-deposited shales in the hanging-wall wedge of considerable thickness in the KGC.

2. The BRC contains both primary and reworked volcanic and volcaniclastic deposits that preserve the record of maximum transport energy in the form of large, progradationally eastward filled mega-scour structures. Infilling probably occurred by pyroclastic surges on land or in very shallow water. Sedimentation was frequently interrupted by veining and other, in places explosive, hydrothermal processes (see Section 4).

3. The BRC shows a regressive-transgressive trend. From the start of the transgressive regime onwards, the system developed, half-way unit 2, a closed, probably wave-dominated coastline with coastal lakes. Pronounced 8-20 m rhythmicity within BRC units 2 and 3 is tentatively related to orbitally forced sea/groundwater-level changes. The BRC represents a westward-facing basin-margin deposystem, probably with a volcanic edifice in the basin centre.

4. Within BRC units 2 and 3, complex diagenetic structures are found close to funnel-shaped disruptions of the bedding. Distorted sediments within these funnels are Fe-oxidized. In other places Fe-oxide-coated breccia forms the fill. These bedding-discordant structures are interpreted as the result of hydrothermal vents. Moreover, black chert veins, crystal palisades, rare convex-upwards silica sinter lenses, breccia and Fe-oxide pods are interpreted as hydrothermal features, closely related to the growth faults.

5. The KGC consists almost exclusively of reworked volcaniclastic sediments that were mostly deposited subaqueously around base level under the influence of tides. The KGC shows an overall regressive trend, during which the sedimentary environment, was influenced by tidal currents. There are strong indications for the preservation of the corresponding littoral zone westward within the Coppin Gap Greenstone Belt and of the landward zone of this tidal lagoon to the east.

6. In both areas, silicification led to excellent preservation of sedimentary textures and structures in some places, and their destruction elsewhere. Silicification was a contemporaneous and early diagenetic, multiphase process, which occurred with varying intensity throughout the sedimentary succession.

\section{Acknowledgements}

This work forms part of the Earth's Earliest Sedimentary Basins project of Utrecht University, in cooperation with the University of Cape Town. Fieldwork was supported by the Stichting Dr. Schürmannfonds, grants 1998/14-2001/14, 2002/10, and 2005/32. Utrecht University MSc students O. Houtzager, I.M.A. Vos and K.L. Louzada took part in the fieldwork. We thank P.W. Fralick, P. Haughton, F. Westall and the anonymous reviewers for comments on this and earlier versions of the manuscript.

\section{References}

Ashley, G.M., Southard, J.B., Boothroyd, J.C., 1982. Deposition of climbing-ripple beds: a flume simulation. Sedimentology 29, 67-79.

Cas, R.A.F., Wright, J.V., 1987. Volcanic Successions: Modern and Ancient. Allen \& Unwin, London, $528 \mathrm{pp}$.

Cuevas Gozalo, M., de Boer, P.L., 1991. Tide-influenced fluvial deposits; examples from Eocene of the Southern Pyrenees. In: Marzo, M., Puigdefàbregas, C. (Eds.) Guidebook Series of the 4th International Conference on Fluvial Sedimentology. Generalitat de Catalunya, p. 93 pp.

De Boer, P.L., 1998. Intertidal sediments: composition and structure. In: Eisma, D. (Ed.), Intertidal Deposits: River Mouths, Tidal Flats, and Coastal Lagoons. CRC Marine Sciences Series, pp. 345-361.

de Boer, P.L., Oost, A.P., Visser, M.J., 1989. The diurnal inequality of the tide as a parameter for recognizing tidal influences. Journal of Sedimentary Petrology 59, 912-921.

De Ronde, C.E.J., Channer, D.M., Spooner, d.E.T.C., 1997. Archaean fluids. In: De Wit, M.J., Ashwal, L.D. (Eds.), Greenstone Belts. Oxford Monographs on Geology and Geophysics. Clarendon Press, Oxford, pp. 309-335.

De Ronde, C.E.J., De Wit, M.J., Spooner, E.T.C., 1994. Early Archean (>3.2 Ga) Fe-oxiderich, hydrothermal discharge vents in the Barberton Greenstone Belt, South Africa. Geol. Soc. Am. Bull. 106, 86-104.

De Ronde, C.E.J., De Wit, M.J., Spooner, E.T.C., Channer, D.M.deR., Christenson, B.W. Bray, C.J., Faure, K., 2004. Ironstone pods in the Archean Barberton greenstone belt, South Africa: Earth's oldest seafloor hydrothermal vents reinterpreted as Quaternary subaerial springs: Comment and Reply. Geology, 32, Online Forum, e68-e69.

De Vries, S.T., 2004. Early Archaean sedimentary basins: depositional environment and hydrothermal systems. Examples from the Barberton and Coppin Gap Greenstone Belts. PhD Thesis, Utrecht University. Geologica Ultraiectina 244 160 pp.(available from http://igitur-archive.library.uu.nl/dissertations/20041203-111621/).

De Vries, S.T., Nijman, W., Armstrong, R.A., 2006a. Growth-fault structure and stratigraphic architecture of the Buck Ridge volcano-sedimentary complex, upper Hooggenoeg Formation, Barberton Greenstone Belt, South Africa. Precambrian Res. 149, 77-98.

De Vries, S.T., Nijman, W., Wijbrans, J.R., Nelson, D.R., 2006b. Stratigraphic continuity and early deformation of the central part of the Coppin Gap Greenstone Belt, Pilbara, Western Australia. Precambrian Res. 147, 1-27. 
De Vries, S.T., Touret, J.L.R., 2007. Early Archaean hydrothermal fluids; a study of inclusions from the $\sim 3.4 \mathrm{Ga}$ Buck Ridge Chert, Barberton Greenstone Belt, South Africa. Chem. Geol. 237, 289-302.

De Wit, M.J., 1983. Notes on a preliminary 1:25000 geological map of the southern part of the Barberton greenstone belt. In: Anhaeusser, C.R. (Ed.), Contributions to the Geology of the Barberton Mountain Land. Geol. Soc. South Afr. Spec. Publ, 9, 185-187 and map.

De Wit, M.J., Hart, R., Martin, A., Abbott, P., 1982. Archaean Abiogenic and Probable Biogenic Structures Associated with Mineralized Hydrothermal Vent Systems and Regional Metasomatism, with Implications for Greenstone Belt Studies. Econ. Geol. 77, 1783-1801.

Eriksson, K.A., Simpson, E.L., 2000. Quantifying the oldest tidal record: the $3.2 \mathrm{Ga}$ Moodies Group, Barberton Greenstone Belt, South Africa. Geology 28, 831-834.

Fisher, R.V., Schmincke, H.-U., 1984. Pyroclastic Rocks. Springer-Verlag, Berlin, 471 pp.

Harms, J.C., Southard, J.B., Spearing, D.R., Walker, R.G., 1975. Depositional environments as interpreted from primary sedimentary structures and stratification sequences. Soc. Econ. Paleont. Mineral. Short Course 2, 161 pp.

Hickman, A.H., 2008. Regional review of the 3426-3350 Ma Strelley Pool Formation, Pilbara Craton, Western Australia. GSWA Record 2008/15, 27 p.

Hofmann, A., Harris, C., 2008. Silica alteration zones in the Barberton greenstone belt: A window into subseafloor processes 3.5-3.3 Ga ago. Chem. Geol. 257, 224-242.

Holland, H.D., 1972. The geologic history of sea water-an attempt to solve the problem. Geochim. Cosmochim. Acta 36, 637-651.

Johnson, H.D., 1977. Sedimentation and water escape structures in some late Precambrian shallow marine sandstones from Finnmark, North Norway. Sedimentology 24, 389-411.

Kröner, A., Byerly, G.R., Lowe, D.R., 1991. Chronology of early Archaean granitegreenstone evolution in the Barberton Mountain Land, South Africa, based on precise dating by single zircon evaporation. Earth Planet. Sci. Lett. 103, 41-54.

Lowe, D.R., 1999. Petrology and sedimentology of cherts and related silicified sedimentary rocks in the Swaziland Supergroup. In: Lowe, D.R., Byerly, G.R. (Eds), Geologic Evolution of the Barberton Greenstone Belt, South Africa. Geol. Soc.Am. Spec. Pap. 329, 83-114

Lowe, D.R., Byerly, G.R., 1999. Stratigraphy of the west-central part of the Barberton Greenstone Belt, South Africa. In: Lowe, D.R., Byerly, G.R. (Eds), Geologic Evolution of the Barberton Greenstone Belt, South Africa. Geol. Soc.Am. Spec. Pap. 329, 1-36.

Lowe, D.R., Byerly, G.R., 2003. Ironstone pods in the Archean Barberton greenstone belt. South Africa: Earth's oldest seafloor hydrothermal vents reinterpreted as Quaternary subaerial springs. Geology 31, 909-912.

Lowe, D.R., Byerly, G.R., 2004. Ironstone pods in the Archean Barberton greenstone belt, South Africa: Earth's oldest seafloor hydrothermal vents reinterpreted as Quaternary subaerial springs: Reply. Geology, 32, Online Forum, e69.

Lowe, D.R., Byerly, G.R., 2007. Ironstone bodies of the Barberton greenstone belt. South Africa: Products of a Cenozoic hydrological system, not Archean hydrothermal vents! Geolog. Soc. Am. Bull. 119, 65-87.

Lowe, D.R., Byerly, G.R., Ransom, B.L., Nocita, B.W., 1985. Stratigraphic and sedimentological evidence bearing on structural repetition in early Archean rocks of the Barberton Greenstone Belt. South Africa. Precambrian Res. 27, 165-186.

Lowe, D.R., Fisher Worrell, G., 1999. Sedimentology, mineralogy, and implications of silicified evaporites in the Kromberg Formation, Barberton Greenstone Belt, South Africa. In: Lowe, D.R., Byerly, G.R. (Eds), Geologic Evolution of the Barberton Greenstone Belt, South Africa. Geol. Soc. Am. Spec. Pap. 329, pp. 167-188.

Maliva, R.G., Siever, R., 1988. Diagenetic replacement controlled by force of crystallization. Geology 16, 688-691.

Mazumder, R., Rodríguez-López, J.P., Arima, M., Van Loon, A.J., 2009. Palaeoproterozoic seismites (fine-grained facies of the Chaibasa Formation, east India) and their soft-sediment deformation structures. In: Reddy, S.M., Mazumder, R., Evans, D.A.D., Collins, A.S. (Eds), Palaeoproterozoic Supercontinents and Global Evolution. Geol. Soc., London, Spec. Publication 323, 301-318.

Montenat, C., Barrier, P., Ott d'Estevou, P., Hibsch, C., 2007. Seismites: an attempt at critical analysis and classification. Sediment. Geol. 196, 5-30.

Myrow, P.M., Fischer, W., Goodge, J.W., 2002. Wave-modified turbidites: combinedflow shoreline and shelf deposits, Cambrian, Antarctica. J. Sedim. Res. 72, 641-656.
Myrow, P.M., Tice, L., Archuleta, B., Clark, B., Taylor, J.F., Ripperdan, R.L., 2004 Flat-pebble conglomerate: its multiple origins and relationship to metre-scale depositional cycles. Sedimentology 51, 973-996.

Nijman, W., De Bruijne, C.H., Valkering, M.E., 1998a. Growth fault control of Early Archaean cherts, barite mounds and chert-barite veins, North Pole Dome, Eastern Pilbara, Western Australia. Precambrian Res. 88, 25-52. (Re-edition in 1999 Precambrian Res. 95, 247-274).

Nijman, W., De Vries, S.T., 2004. Early Archaean crustal collapse structures and sedimentary basin dynamics. In: Eriksson, P.G., Altermann, W., Nelson, D.R., Mueller, W.U., Catuneanu, O. (Eds.), The Precambrian Earth: Tempos and Events. Developments in Precambrian Geology 12,139-155.

Nijman, W., De Vries, S.T., 2009. Geological map of the Lower Archaean Buck Ridge volcano-sedimentary complex, Barberton Greenstone Belt, Republic of South Africa. 3 Map sheets and explanatory not, CD-Rom edition. Faculty of Geosciences, Utrecht University, The Netherlands ISBN: 978-90-5744-153-0. [available from: Sedimentology Group, Dept. of Earth Sciences, Utrecht University].

Nijman, W., Willigers, B.A., Krikke, A., 1998b. Tensile and compressive growth structures: relationships between sedimentation, deformation and granite intrusion in the Archaean Coppin Gap greenstone belt, Eastern Pilbara, Western Australia. Precambrian Res, 88, 83-107. (Re-edition in 1999, Precambrian Res. 95 277-302)

Nio, S.D., Yang, C.S., 1991. Diagnostic attributes of clastic tidal deposits: a review. In: Smith, D.G., Reinson, G.E., Zaitlin, B.A., Rahmani, R.A. (Eds), Clastic tidal sedimentology. Canadian Soc. of Petroleum Geology Memoir 16, $3-28$.

Orberger, B., Rouchon, V., Westall, F., De Vries, S.T., Pinti, D.L., Wagner, C., Wirth, R, Hashizume, K., 2006. Microfacies and origin of some Archean cherts (Pilbara, Australia). In: Reimold, W.U., Gibson, R.L., Processes on the Early Earth. GSA Special Paper 405, 133-156.

Orton, G.J., 1996. Volcanic environments. In: Reading, H.G., Sedimentary environments: Processes, Facies, and Stratigraphy. Third edition, Blackwell Science, Cambridge, 485-587.

Purdy, E.G., 1963. Recent calcium carbonate facies of the Great Bahama Bank [Part] 2: Sedimentary facies. J. Geol. 71, 472-497.

Rouchon, V., Orberger, B., 2008. Origin and mechanisms of K-Si-metasomatism of ca. 3.4-3.3 Ga volcaniclastic deposits and implications for Archean seawater evolution: Examples from cherts of Kittys Gap (Pilbara craton, Australia) and Msauli (Barberton Greenstone Belt, South Africa). Precambrian Res. 165, 169189.

Tice, M.M., Lowe, D.R., 2004. Photosynthetic microbial mats in the 3,416-Myr-old ocean. Nature $431,549-552$.

Tice, M.M., Lowe, D.R., 2006. The origin of carbonaceous matter in pre-3.0 Ga greenstone terrains: A review and new evidence from the 3.42 Ga Buck Reef Chert Earth-Sc. Rev. 76, 259-300.

Van der Boorn, S.H.J.M., Van Bergen, M.J., Nijman, W., Vroon, P.Z., 2007. Dual role of seawater and hydrothermal fluids in Early Archean chert formation: Evidence from silicon isotopes. Geology 35, 939-942.

Van Kranendonk, M.J., 2000. Geology of the North Shaw 1:100 000 sheet. Western Australia Geological Survey, 1:100 000 Geological Series Explanatory Notes, 86 p.

Van Kranendonk, M.J., Hickman, A.H., Williams, I.R., Nijman, W., 2001. Archaean geology of the East Pilbara granite-greenstone terrane, Western Australia-A field guide. GSWA Record 2001/9, $134 \mathrm{p}$.

Varghese, G., George, J., 2004. Pattern formation in reaction diffusion systems: a moving boundary model. Solid State Phenomena 97-98, 125-132.

Viljoen, M.J., Viljoen, R.P., 1969. The Geological and Geochemical Significance of the Upper Formations of the Onverwacht Group, Upper Mantle Project. Geol. Soc. South Afr. Spec. Publ. 2, 113-151.

Visser, M.J., 1980. Neap-spring cycles reflected in Holocene sub-tidal large-scale bedform deposits: a preliminary note. Geology 8, 543-546.

Westall, F., De Vries, S.T., Nijman, W., Rouchon, V., Orberger, B., Pearson, V., Watson, J., Verchovsky, A., Wright, I., Rouzaud, J.-N., Marchesini, D., Severine, A., 2006. The 3446 Ga "Kitty's Gap Chert”, an early Archean microbial ecosystem. In: Reimold, W.U., Gibson, R.L. (Eds), Processes on the Early Earth. GSA Special Paper 405, 105-131. 